Louisiana State University

LSU Digital Commons

$9-1-2020$

\title{
A Numerical Investigation of Wave-Supported Gravity Flow During Cold Fronts Over the Atchafalaya Shelf
}

\author{
Zhengchen Zang \\ Louisiana State University \\ Z. George Xue \\ Louisiana State University \\ Kehui Xu \\ Louisiana State University \\ Celalettin E. Ozdemir \\ Louisiana State University \\ Qin Chen \\ Northeastern University
}

See next page for additional authors

Follow this and additional works at: https://digitalcommons.Isu.edu/geo_pubs

\section{Recommended Citation}

Zang, Z., Xue, Z., Xu, K., Ozdemir, C., Chen, Q., Bentley, S., \& Sahin, C. (2020). A Numerical Investigation of Wave-Supported Gravity Flow During Cold Fronts Over the Atchafalaya Shelf. Journal of Geophysical Research: Oceans, 125 (9) https://doi.org/10.1029/2019JC015269

This Article is brought to you for free and open access by the Department of Geology and Geophysics at LSU Digital Commons. It has been accepted for inclusion in Faculty Publications by an authorized administrator of LSU Digital Commons. For more information, please contact ir@lsu.edu. 


\section{Authors}

Zhengchen Zang, Z. George Xue, Kehui Xu, Celalettin E. Ozdemir, Qin Chen, Samuel J. Bentley, and Cihan Sahin 


\section{JGR Oceans}

\author{
RESEARCH ARTICLE \\ 10.1029/2019JC015269 \\ Key Points: \\ - Model results well reproduce \\ hydrodynamics and WSFM \\ dynamics during cold fronts \\ - WSFM transport results in onshore \\ erosion and offshore deposition over \\ the Atchafalaya inner shelf \\ - Bed consolidation might influence \\ WSFM concentration after several \\ rounds of erosion
}

Correspondence to:

Z. Xue,

zxue@lsu.edu

\section{Citation:}

Zang, Z., Xue, Z. G., Xu, K., Ozdemir, C. E., Chen, Q., \& Bentley, S. J., et al. (2020). A numerical investigation of wave-supported gravity flow during cold fronts over the Atchafalaya shelf. Journal of Geophysical Research: Oceans, 125, e2019JC015269. https:// doi.org/10.1029/2019JC015269

Received 7 MAY 2019

Accepted 11 AUG 2020

Accepted article online 19 AUG 2020

(C)2020. American Geophysical Union. All Rights Reserved.

\section{A Numerical Investigation of Wave-Supported Gravity Flow During Cold Fronts Over the Atchafalaya Shelf}

\author{
Zhengchen Zang $^{1,2} \mathbb{D}$, Z. George Xue ${ }^{1,3,4} \mathbb{D}$, Kehui Xu ${ }^{1,4} \mathbb{D}$, Celalettin E. Ozdemir ${ }^{3,4,5} \mathbb{D}$, \\ Qin Chen ${ }^{6}$ (D), Samuel J. Bentley ${ }^{4,7}$ (D), and Cihan Sahin ${ }^{8}$ (D) \\ ${ }^{1}$ Department of Oceanography and Coastal Sciences, Louisiana State University, Baton Rouge, LA, USA, ${ }^{2}$ Now at Woods \\ Hole Oceanographic Institution, Woods Hole, MA, USA, ${ }^{3}$ Center for Computation and Technology, Louisiana State \\ University, Baton Rouge, LA, USA, ${ }^{4}$ Coastal Studies Institute, Louisiana State University, Baton Rouge, LA, USA, \\ ${ }^{5}$ Department of Civil and Environmental Engineering, Louisiana State University, Baton Rouge, LA, USA, ${ }^{6}$ Department of \\ Civil and Environmental Engineering, Northeastern University, Boston, MA, USA, ${ }^{7}$ Department of Geology and \\ Geophysics, Louisiana State University, Baton Rouge, LA, USA, ${ }^{8}$ Department of Civil Engineering, Yildiz Technical \\ University, Istanbul, Turkey
}

Abstract Wave-supported fluid mud (WSFM) plays an important role in sediment downslope transport on the continental shelves. In this study, we incorporated WSFM processes in the wave boundary layer (WBL) into the Community Sediment Transport Modeling System (CSTMS) on the platform of the Coupled Ocean-Atmosphere-Wave-and-Sediment Transport modeling system (COAWST). The WSFM module was introduced between the bottommost water layer and top sediment layer, which accounted for the key sediment exchange processes (e.g., resuspension, vertical settling, diffusion, and horizontal advection) at the water-WBL and WBL-sediment bed boundaries. To test its robustness, we adapted the updated model (CSTMS + WBL) to the Atchafalaya shelf in the northern Gulf of Mexico and successfully reproduced the sediment dynamics in March 2008, when active WSFM processes were reported. Compared with original CSTMS results, including WSFM module weakened the overall intensity of sediment resuspension, and the CSTMS + WBL model simulated a lutocline between the WBL and overlying water due to the formation of WSFM. Downslope WSFM transport resulted in offshore deposition $(>4 \mathrm{~cm})$, which greatly changed the net erosion/deposition pattern on the inner shelf off the Chenier Plain. WSFM flux was comparable with suspended sediment flux (SSF) off the Atchafalaya Bay, and it peaked along the Chenier Plain coast where wave activities were strong and the bathymetric slope was steep. The influence of fluvial sediment supply on sediment dynamics was limited in the Atchafalaya Bay. Sensitivity tests of free settling, flocculation, and hindered settling effects suggested that sediments were transported further offshore due to reduced settling velocity in the WBL once fluid mud was formed. Although sediment concentration in the WBL was sensitive to surface sediment critical shear stress, cohesive bed behavior was less important in WSFM dynamics when compared with strong hydrodynamic during cold fronts.

Plain Language Summary Fluid mud is an intermediate stage between a consolidated seafloor and dilute fine sediment suspension. Its high density $(>10 \mathrm{~g} / \mathrm{L})$ and downslope movement are important in sediment transport over the inner continental shelf (water depths $<15 \mathrm{~m}$ ). In this study we adopted a numerical model to simulate fluid mud transport on the Atchafalaya continental shelf in coastal Louisiana. We found that fluid mud formed during the passages of cold fronts, and its transport contributed to offshore sediment deposition. This downslope sediment transport process was more affected by the settling velocity of sediment particles rather than fluvial supply from the Atchafalaya River or sediment consolidation on the seabed.

\section{Introduction}

As the most volumetrically abundant natural material on the Earth's surface, mud (grain size $<63 \mu \mathrm{m}$ ) plays a key role in fluvial sediment delivery, land building, and subsidence in coastal regions (Aplin et al., 1999; Macquaker et al., 2010; Meade \& Moody, 2010; Neill \& Allison, 2005; Nittrouer et al., 1991). Mud deposits have been widely observed seaward of active river systems and their morphological features are determined by both fluvial discharge and oceanic processes (Hanebuth et al., 2015; Walsh \& Nittrouer, 2009). They usually have a high content of organic matter and show sign of bioturbation (Allison et al., 2000; Bentley 
et al., 2006; Bentley \& Nittrouer, 2003; Bianchi et al., 2002; Goñi et al., 2006). Furthermore, records of pollution and human activities suggest that mud dynamics can impact the transport of contaminants such as heavy metals, microplastics, and pesticides in the aquatic environment (Adams et al., 2007; Dail et al., 2007; Huang et al., 2014; Martin, 2002; Trefry \& Presley, 1976). In navigation channels, the existence of aggregated mud layer near the bottom can introduce high drag resistance against the propulsion of vessels (Mehta et al., 2014). Therefore, understanding the controlling mechanisms of muddy deposits is important to geomorphology, oceanic biogeochemical process, ocean pollution, and coastal engineering.

Fluid mud, an intermediate stage between consolidated deposition and dilute fine sediment suspension, is a fine-grained, non-Newtonian slurry characterized by high concentration ( $>10 \mathrm{~g} / \mathrm{L})$ and hindered settling (Ross \& Mehta, 1989; Sahin et al., 2012; Sheremet et al., 2005). The ubiquity of fluid mud has been reported globally in the regions of freshwater influence (ROFI) due to the high discharge of fine sediment-laden rivers (Jaramillo et al., 2009; Ma et al., 2010; McAnally et al., 2007; Traykovski et al., 2000; Wang et al., 2010). Fluid mud's importance for cross-shore sediment transport has been well-documented (Hale et al., 2014; Hale \& Ogston, 2015; Kineke et al., 2006; Ogston et al., 2000; Traykovski et al., 2000; Wang et al., 2010). Unlike self-sustaining turbidity currents, fluid mud, when moving down mild slope $\left(<0.7^{\circ}\right)$, requires additional turbulence provided by ambient waves and currents to be sustained (Wright et al., 2001). Based upon different suspension maintenance mechanisms, fluid mud can be categorized as (i) wave-supported fluid muds (WSFM; Harris et al., 2005), which is also the focus of this study, (ii) current-supported fluid muds (CSFM; Wang et al., 2010), and (iii) wave-current-supported fluid muds (WCSFM; Ma et al., 2010). WSFM mainly requires near-bed turbulence introduced by wave orbital velocity within the wave boundary layer (WBL) to maintain high concentration sediment suspension (Friedrichs \& Scully, 2007; Traykovski et al., 2000, 2007). In return, high density fluid muds with enhanced viscosity effectively attenuate wave energy in different spectral bands (Sheremet et al., 2005, 2011; Sheremet \& Stone, 2003; Winterwerp et al., 2007). Under the influence of gravity, high density fluid muds move downslope across shelf to the deeper regions until the decreased wave-induced shear can no longer support the total amount of sediments in the WBL (Friedrichs \& Scully, 2007; Traykovski et al., 2015; Wright \& Friedrichs, 2006). WSFM is usually reported during energetic wave activities associated with the cold front or hurricane passages (Kineke et al., 2006; Sheremet et al., 2005). In response to energetic events, fine particles can be resuspended from the seabed creating WSFM which is capable of propagating downslope rapidly from the clinothem topsets to the more steeply dipping foresets, resulting in a higher sediment deposition rate offshore (Denommee et al., 2016; Friedrichs \& Scully, 2007; Neill \& Allison, 2005; Traykovski et al., 2007; Wright \& Friedrichs, 2006).

The research area of this study is the Atchafalaya shelf in the northern Gulf of Mexico (nGoM), which is characterized by shallow water depth and gentle gradient (Rotondo \& Bentley, 2003). It receives large amount of fluvial discharge ( $237 \mathrm{~km}^{3} /$ year water flux and $71.5 \mathrm{Mt} /$ year sediment load) from the Atchafalaya River, a distributary of the lower Mississippi River (Allison et al., 2012). Freshwater discharge of the Atchafalaya River accounts for $\sim 30 \%$ of total Mississippi River discharge after the construction of Old River Control Structure upstream near Simmesport, LA (Neill \& Allison, 2005). Approximately 70\% of the Atchafalaya water flux flows into the Atchafalaya Bay through the Atchafalaya Outlet, and the remainder passes through the Wax Lake Outlet (Kineke et al., 2006). The sediment diversion to the Atchafalaya River since the 1970s resulted in the growth of sandy delta lobes and land/subaqueous delta accretion in the Atchafalaya Bay (Draut, Kineke, Huh, et al., 2005; Neill \& Allison, 2005). Previous volumetric calculations estimated that less than half of the fluvial sediment was retained in the Atchafalaya Bay, and the rest was transported into the nGoM (Wells et al., 1984). As an important sediment transport process, WSFM dispersal has been reported over the Atchafalaya subaqueous delta and Chenier Plain mudflats during the passage of cold fronts and tropical storms (Allison et al., 2000; Jaramillo, 2008; Kineke et al., 2006; Safak et al., 2010; Wells \& Kemp, 1981). The existence and significance of WSFM-induced seaward sediment transport over the Atchafalaya shelf are further supported by isotope chronologies (Allison \& Neill, 2002; Draut, Kineke, Velasco, et al., 2005; Rotondo \& Bentley, 2003). Due to the high-intensity wave activities during cold fronts, WSFM mostly occurs in winter and early spring. During a winter storm, the muddy topset/foreset of the subaqueous delta near the Atchafalaya Bay mouth goes through a cycle of liquefaction, erosion, and deposition, which lead to fluid mud formation followed by consolidation (Sahin et al., 2012). Such a cycle results in the formation of two fluid mud layers above the Atchafalaya clinoform: The first one is 
introduced by seafloor liquefaction and the second one is caused by advection and suspended sediment settling (Jaramillo et al., 2009). Along the Chenier Plain coast, fluid mud forms following the cold front's approach and potentially contributes to the landward sediment transport because of coastal upwelling and wave energy attenuation (Kineke et al., 2006). The sedimentary fabrics (such as ripple cross-bedding and intercalated silts and clays) in sediment cores, as well as ${ }^{210} \mathrm{~Pb}$ profiles and X-radiographs over the Chenier Plain highlighted the importance of WSFM transport over the mud deposit (Denommee et al., 2018).

Existing WSFM field studies on the Atchafalaya shelf have relied on tripods, anchor stations, buoy stations, and sediment cores (Denommee et al., 2018; Jaramillo et al., 2009; Kineke et al., 2006; Safak et al., 2010; Sahin et al., 2012; Sheremet et al., 2011). Direct measurements of hydrodynamic and sediment quantities at the bottom boundary layer (BBL) are still limited. In addition, sampling fluid muds and measuring gravity-induced sediment flux on shelf scale are still challenging. These difficulties inhibit a thorough understanding of the influence of fluid mud process on sediment dynamics. As an alternative method, numerical models have been widely developed to investigate fluid mud process and its interaction with hydrodynamics. The wave model by Sheremet et al. (2011) revealed that mud-induced energy dissipation is crucial during wave propagation although nonlinear three-wave interactions play a key role in the shape of the frequency distribution of the dissipation rate. Safak et al. (2010) and Sahin et al. (2012) applied the one-dimensional cohesive BBL model by Hsu et al. (2009) to the Atchafalaya shelf and concluded that the existence of fluid mud controls turbulent kinetic energy balance and state of the seafloor. The idealized 1-D (vertical) eddy-viscosity BBL model developed by Trowbridge and Kineke (1994) revealed that the vertical structure of turbid bottom layer was controlled by the characteristics of sediment particles (e.g., settling velocity) and hydrodynamics (e.g., bottom friction velocity). Considering the highly turbid hyperpycnal flow and wave-supported resuspension, the 1-D model in the cross-shelf direction developed by Friedrichs and Wright (2004) indicated that the equilibrium convex clinoform profile is determined jointly by wave height and fluvial sediment supply. Scully et al. (2003) employed a 2-D (depth-averaged for the WBL) WSFM model to the Eel River continental shelf during flood periods and reasonably well simulated the offshore fine sediment deposit over the midshelf, which accounts for $26 \%$ of the fine sediment discharged by the Eel River over four flood seasons from 19941995 to 1997-1998. The same model was applied to the Po River subaqueous delta in the Adriatic Sea, and most of the deposition was detected near where the offshore slope first ceases to increase (Friedrichs \& Scully, 2007). Harris et al. (2004, 2005) further included settling process into a 2-D (depth-averaged for the WBL) WSFM model coupled to a 3-D model of dilute suspension transport, the Estuarine and Coastal Ocean Model-Sediment (ECOM-SED; Blumberg \& Mellor, 1987), and simulated a 5-10 cm deposition over the midshelf seaward off the Eel River during the January 1997 flood. In the same study, for the cross-shelf component of flow, the WSFM sediment flux was larger than the dilute suspended flux.

Although previous field and numerical studies significantly furthered our understanding on WSFM dynamics and its interaction with hydrodynamics, only a few studies (e.g., Denommee et al., 2018; Neill \& Allison, 2005) focused on the mechanisms behind the formation of the offshore depo-center on the Atchafalaya shelf, which is possibly the results of WSFM transport. In addition, there is a paucity of a comprehensive understanding on the concurrent impact of fluvial discharge, waves, and winds on shelf scale WSFM processes. In this study, we adapted the WSFM model by Harris et al. (2004, 2005) into the Community Sediment Transport Modeling System (CSTMS; Warner et al., 2008) on the platform of the Coupled Ocean-Atmosphere-Wave-and-Sediment Transport modeling system (COAWST; Warner et al., 2008, 2010). Compared with its original platform (ECOM-SED), COAWST incorporates several state-of-the-art numerical models, newly developed sediment modules (e.g., Sherwood et al., 2018), and supports coupling among the atmospheric, wave, and ocean models. Specifically, the CSTMS of COAWST can represent cohesive bed behavior (Sherwood et al., 2018), which could significantly alter sediment dynamics in a muddy deposition environment like the Atchafalaya shelf (Kineke et al., 2006; Rinehimer et al., 2008). The objectives of this study are (i) to understand WSFM's contribution to the depositional pattern over the Atchafalaya shelf, (ii) to quantify sediment fluxes due to fluid mud and dilute suspended sediment during cold fronts, and (iii) to evaluate model sensitivity to fluvial discharge and sediment parameterizations. 
(a) Atchafalaya Shelf and tripods' locations

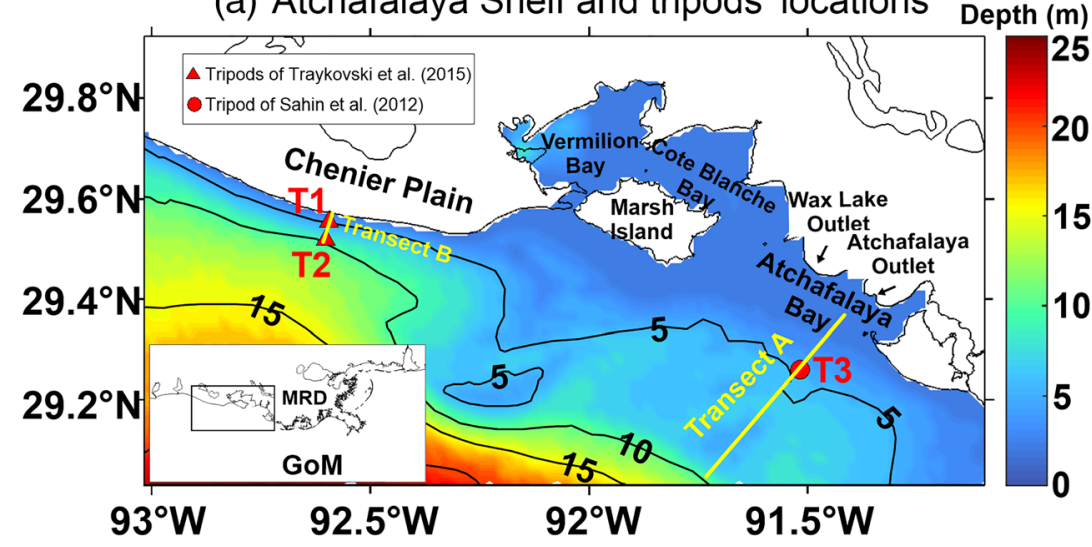

(b) Mud Fraction

(\%)

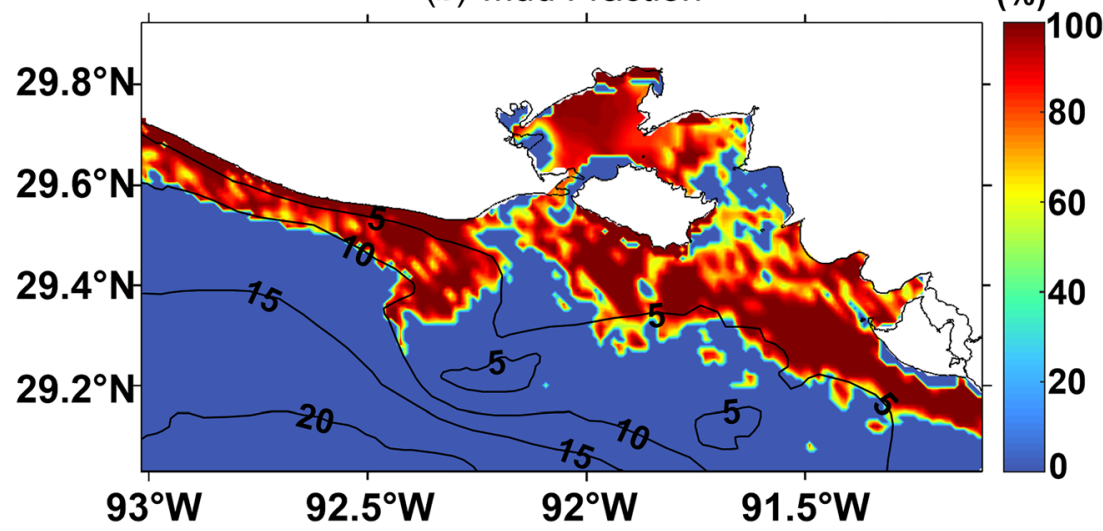

Figure 1. The northern Gulf of Mexico (nGoM) model domain (lower left of panel a) and Atchafalaya shelf overlaid with water depth (color-shading) and locations of tripods (T1, T2, and T3) from Traykovski et al. (2015) and Sahin et al. (2012). The two yellow lines represent two transects across the Atchafalaya Bay (Transect A) and Chenier Plain inner shelf (Transect B). The two transects (going through the tripods) are cutoff at $10 \mathrm{~m}$ depth. Panel (b) shows mud fraction (unit: \%) over the sea floor from usSEABED (Williams et al., 2007). Isobaths contoured at 5, 10, 15, and $20 \mathrm{~m}$.

\section{Model Setup}

COAWST is an open source community model that incorporates three state-of-the-art numerical models (the Weather Research and Forecasting model [WRF, v 3.7.1, Skamarock et al., 2005], ROMS [svn 797, Shchepetkin \& McWilliams, 2005; Haidvogel et al., 2008], and the Simulating Waves Nearshore model [SWAN, v 41.01AB, Booij et al., 1999]). In this study, we activated the coupling between the ROMS and SWAN and adapted the wave-supported gravitational flow module developed by Harris et al. (2004, 2005) to ROMS's sediment transport model (CSTMS). A 25-day coupled ocean-wave-sediment transport simulation was conducted for the period of 1-25 March 2008. During the simulation period, there were three cold fronts (hereafter defined as CF1, CF2, and CF3 in chronological order) which increased wave energy and for which observational data were available (Sahin et al., 2012; Traykovski et al., 2015).

\subsection{Hydrodynamic Model (ROMS, SWAN, and Model Coupling)}

ROMS is a three-dimensional, free surface, terrain following model that solves Reynolds-Averaged NavierStokes (RANS) equations based on the hydrostatic and Boussinesq assumptions (Haidvogel et al., 2008). Our model grid covers the nGoM with a horizontal resolution of $1 \mathrm{~km}$ (Figure 1a). A total of 24 vertical stretched terrain following layers were specified to resolve the vertical structure of water column. Initial and boundary conditions (e.g., sea-level, barotropic, and baroclinic current speeds, temperature, and salinity) were extracted from Zang et al. (2019). The Orlanski-type radiation boundary condition was imposed for temperature, salinity, and baroclinic velocities (Orlanski, 1976). The boundary condition for depth-averaged current 
velocity was specified following Flather (1976). The Oregon State University Tidal Inversion Software (OTIS; Egbert \& Erofeeva, 2002) regional tidal solution was interpolated on the model domain as tidal forcing. For buoyancy forcing and meteorological momentum, we used the North American Regional Reanalysis (NARR, https://www.esrl.noaa.gov/psd/data/gridded/data.narr.html) with a $32 \mathrm{~km}$ horizontal resolution. River inputs were obtained from United States Geological Survey (USGS) Water Data for the Nation (http://nwis.waterdata.usgs.gov) at station Melville, LA (monthly mean fluvial sediment concentration: $0.27 \mathrm{~g} / \mathrm{L}$; water flux: 11,057 $\mathrm{m}^{3} / \mathrm{s}$ ). We initialized the 25-day simulation on 1 March 2018 00:00:00 UTC with a time step of $1 \mathrm{~s}$. Current field was free to develop without any benefits from nudging or data assimilation.

We used SWAN to simulate wind wave generation and swell propagation in the nGoM. The grid of SWAN model was the same as that of the ocean model (ROMS). Wave boundary conditions were extracted from a larger domain that covered the entire Gulf of Mexico (Zang et al., 2019). For realistic initialization of the wave model, we conducted an nGoM wave simulation from 2-3 January 2008 and used its restart files as the initial condition. The time step of wave model was $30 \mathrm{~s}$. The physical setup of the wave model was the same as Zang et al. (2018), and the upper limit of frequency range used for computing the swell height was set to $0.2 \mathrm{~Hz}$ (Safak et al., 2010; Sheremet et al., 2005).

COAWST utilizes the Model Coupling Toolkit (MCT; Jacob et al., 2005) to support variable exchange between ocean model (ROMS) and wave model (SWAN). ROMS sends water depth, water level, and barotropic current speed to SWAN and receives the computed parameters (such as wave direction, wave length, significant wave height, wave energy dissipation rate and bottom orbital velocity) from SWAN to estimate the influence of waves to the momentum at the BBL, surface roughness, and wave breaking-induced turbulent energy injection. In this study, we used a wave-current bottom boundary layer model (SSW_BBL; Madsen, 1994) to simulate bottom shear stress induced by currents and waves. The information exchange interval between ROMS and SWAN is $4 \mathrm{~min}$.

\subsection{Sediment Transport Model (CSTMS) and WSFM Module} 2.2.1. CSTMS (Sherwood et al., 2018; Warner et al., 2008)

CSTMS is the sediment model incorporated in COAWST and has been widely used to investigate sediment transport, stratigraphy, and geomorphology in coastal regions (Miles et al., 2015; Moriarty et al., 2014, 2015; Xu et al., 2011; Xu, Mickey, et al., 2016; Xue et al., 2012; Zang et al., 2018; Zeng et al., 2015). Since this study focused on mud transport, we specified one cohesive (mud) and one noncohesive (sand) sediment class. Given that mud-rich WSFM deposits were found over the Atchafalaya inner shelf (Denommee et al., 2016), we simplified noncohesive sediment dynamics by treating sand as a resuspension-resistant sediment class $\left(\tau_{c r i}=100 \mathrm{~Pa}\right)$ in this study. Sediment erosion flux was estimated following Ariathurai and Arulanandan (1978) equation:

$$
E=E_{0}(1-\phi)\left[\frac{\tau_{c w}-\tau_{c r i}}{\tau_{c w}}\right]
$$

where $E_{0}$ is erosion rate. $\tau_{c w}$ and $\tau_{c r i}$ represent bottom shear stress and critical shear stress, respectively. All sediment layers had a porosity $(\phi)$ of 0.5 in this study. Critical shear stress and settling velocity of the cohesive sediment was set to $0.07 \mathrm{~Pa}$ and $0.1 \mathrm{~mm} / \mathrm{s}$, respectively (Xu, Mickey, et al., 2016). In the benchmark run we did not consider critical shear stress variation due to cohesive bed consolidation. The gradient horizontal boundary condition was implemented for sediment to avoid unreal sediment plumes near the boundary (Xu et al., 2011). On the seafloor, we prescribed four sediment layers initially with $1 \mathrm{~m}$ thickness for each layer, and their thicknesses evolved with deposition and erosion. The percentage of cohesive sediment on the seafloor was based on the usSEABED data set (Williams et al., 2007; Figure 1b). Because the WSFM process has been primarily reported on the topset and foreset of the subaqueous delta (water depth < 10 m; Allison et al., 2000; Denommee et al., 2018, 2016; Draut, Kineke, Velasco, et al., 2005), the mud fraction over the seabed was prescribed as zero where water depth exceeded $10 \mathrm{~m}$.

\subsubsection{WSFM Module}

The WBL plays an important role in offshore sediment transport and material exchange between the seafloor and overlying water, especially during strong wave events (Harris et al., 2005; Jaramillo, 2008; Jaramillo et al., 2009; Wright \& Friedrichs, 2006). Following Harris et al. (2004), a new layer was added to represent the WBL between ROMS' bottommost water column layer and the top sediment bed layer 


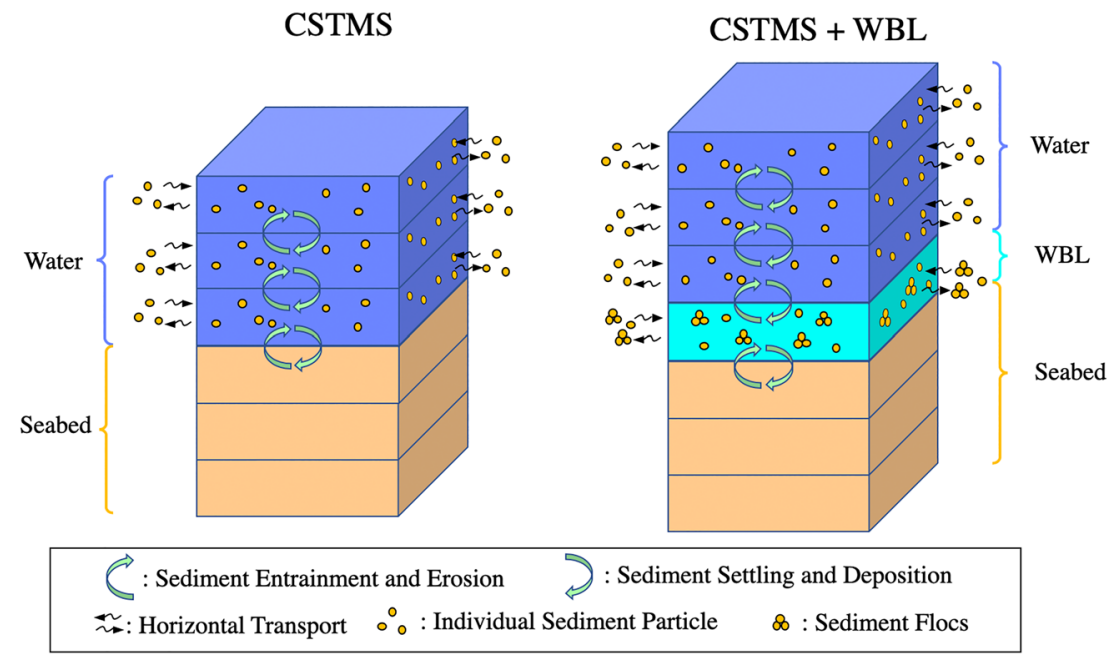

Figure 2. Diagram of original community sediment transport modeling system (CSTMS; left panel) and updated CSTMS model with wave boundary layer (CSTMS + WBL; right panel). (Note: Both water column and seabed have multiple layers).

(Figure 2). Since the WBL is represented using only one layer, sediment concentration and momentum resolved in this module are depth-averaged values. Jaramillo et al. (2009) observed that the lutocline and the top of the WBL coincided, and their height variations were highly correlated with wave forcing over the Atchafalaya shelf. Therefore, the thickness of WBL was estimated using $\delta_{w}=\frac{u_{w}}{\omega}$ ( $u_{w}$ : wave orbital velocity; $\omega$ : wave frequency) to account for stratification between WSFM and bottom water layer following Harris et al. (2004). Different from the original CSTMS model, we set the downward sediment settling flux from the bottommost water layer to the WBL instead of seabed. Similarly, upward suspended sediment flux into the bottom water layer comes from the WBL instead of seabed. To account for stratification between the WSFM and the bottommost water layer, we use and eddy viscosity that changes with the gradient Richardson number to estimate the upward sediment flux ( $E_{w b l}$; Munk \& Anderson, 1948; Ross \& Mehta, 1989; Harris et al., 2004). Sediment exchange between the seabed and the WBL is determined by the sediment erosion flux $(E)$ and settling flux $(D)$. Here, net erosion/deposition in each time step is estimated following Harris and Wiberg (2002):

$$
E-D=\left(c_{e q}-c_{s, w b l}\right) w_{s, w b l} \Delta t
$$

where $c_{s, w b l}$ is sediment concentration in the WBL. The equilibrium concentration $\left(c_{e q}\right)$ is estimated based on Smith and McLean (1977). $w_{s, w b l}$ is sediment settling velocity in the WBL. The given sediment erosion and deposition algorithm is different from Equation 1 used in original CSTMS (Warner et al., 2008).

To estimate the momentum in the WBL $\left(u_{w b l}\right.$ and $\left.v_{w b l}\right)$ and WSFM-induced horizontal sediment flux, the WSFM module uses a linearized Chezy equation that accounts for the velocities of both the WBL and the bottom water layer (Wright et al., 2001). The drag coefficient $C_{D}$ is set to 0.004 based on previous studies (e.g., Friedrichs \& Scully, 2007; Ma et al., 2008). The variation of current speed in the bottommost water layer due to frictional drag between the WBL and overlying water is neglected in this study. The horizontal WSFM-induced sediment fluxes in $x$ - and $y$-directions $\left(Q_{x, w b l}\right.$ and $\left.Q_{y, w b l}\right)$ are equal to $c_{s, w b l} u_{w b l} \delta_{w}$ and $c_{S}$, $w b l v_{w b l} \delta_{w}$, respectively.

Given all the WSFM-related processes mentioned above (i.e. settling, resuspension, diffusion and horizontal advection), the governing equation of WSFM flux in its general form is given below:

$$
\frac{\partial\left(\delta_{w} c_{w b l}\right)}{\partial t}=w_{s, w a t e r} c_{s, w a t e r}+w_{s, w b l}\left(c_{e q}-c_{w b l}\right)+E_{w b l}+\frac{\partial Q_{x, w b l}}{\partial x}+\frac{\partial Q_{y, w b l}}{\partial y}
$$

This equation is identical to the governing equation in Harris et al. (2004). To solve the equation, we employed the 2-D Lax-Wendroff method, which is an explicit second-order scheme both spatially and temporally. 


\subsection{Sensitivity Tests}

Following Harris et al. (2005), we carried out three sets of sensitivity tests to examine the influences of (1) WSFM, (2) riverine sediment inputs, and (3) settling velocity on simulated sediment fields. Additionally, we included cohesive bed behavior in our model to test its potential role in WSFM dynamics.

Cohesive sediment transport over the muddy Atchafalaya shelf is mainly driven by two mechanisms: dilute sediment transport in the water column and gravity-driven downslope WSFM transport near seabed (Kineke et al., 2006; Kolker et al., 2014; Neill \& Allison, 2005). During energetic events (e.g., cold fronts and hurricanes), both mechanisms are potentially important to sediment transport, yet their relative contributions were understudied due to the difficulties in shelf scale field measurements or the lack of WSFM in existing models. To understand the significance of WSFM in terms of sediment transport over the Atchafalaya shelf, we compared calculations of sediment flux and patterns of erosion/deposition made using the model that included the WSF (CSTMS + WBL) to those made using the original CSTMS with an identical model configuration. Sediment fluxes in the water column $\left(S S F_{\text {water }}\right)$ and the WBL $\left(S S F_{W B L}\right)$ were estimated as

$$
\begin{gathered}
S S F_{\text {water }}=\sum_{i=1}^{N} S S C_{i} \cdot u_{i} \cdot h_{i}, \\
S S F_{W B L}=C_{w b l} \cdot \delta_{w} \cdot u_{w b l},
\end{gathered}
$$

where $S S C_{i}$ and $u_{i}$ are suspended sediment concentration (unit: g/L) and current speed (unit: $\mathrm{m} / \mathrm{s}$ ) in the $i$ th layer. $N$ is the number of vertical layers (24 in this study), and $h$ is the thickness of each layer (unit: $\mathrm{m}$ ).

Given that cold front-induced WSFM transport mainly happens in winter and spring, during which the Atchafalaya River is in its flood season and its flux changes drastically, it is necessary to understand the response of WSFM dynamics to different riverine sediment discharge scenarios. The importance of fluvial sediment discharge in controlling the intensity of dilute and gravity-driven sediment transport has been confirmed over the Eel River shelf (Harris et al., 2005). Here we modified fluvial sediment discharge to test the impact of Atchafalaya riverine sediment supply on sediment dynamics over the shelf. To avert the influence of estuarine hydrodynamics variation with a changing river flow, we kept water discharge unchanged $\left(11,057 \mathrm{~m}^{3} / \mathrm{s}\right.$ ) but doubled the fluvial SSC (from 0.28 to $0.56 \mathrm{~g} / \mathrm{L}$ ) in one experiment and halved the fluvial SSC (from 0.28 to $0.14 \mathrm{~g} / \mathrm{L}$ ) in the other.

Unlike noncohesive sediments, settling velocity of cohesive sediment varies greatly with concentration, particle properties, and hydrodynamics (Fugate \& Friedrichs, 2002; Gratiot \& Manning, 2004; Milligan \& Hill, 1998). For fluid mud transport simulations, settling velocity parameterization was even more challenging due to the wide range of sediment concentration (Hill et al., 2000). Harris et al. (2004, 2005) found that hindered settling due to flocculation could increase WSFM offshore transport distance on the Eel shelf. In the benchmark run, we set the settling velocity of cohesive sediment in the WBL following Mehta (1996):

$$
w_{s, w b l}=\left\{\begin{array}{l}
w_{s f}\left(c_{s, w b l}<C 1\right) \\
w_{s h}\left(c_{s, w b l} \geq C 1\right)
\end{array}\right.
$$

where $C 1$ is the fluid mud concentration threshold $(10 \mathrm{~g} / \mathrm{L})$. When sediment concentration in the WBL $\left(c_{s, w b l}\right)$ is lower than $C 1$, particle interaction is negligible and settling velocity becomes equal to free settling velocity $\left(w_{s f} ; 0.1 \mathrm{~mm} / \mathrm{s}\right)$. If $c_{s, w b l}$ exceeds $C 1$, settling velocity decreases to $0.01 \mathrm{~mm} / \mathrm{s}\left(w_{s h}\right)$ as a result of the combination of upward return flow and wake generation, increased effective viscosity, and reduced specific gravity of the flocs (hindered settling; Cheng, Yu, Hsu, Ozdemir, \& Balachandar, 2015; Dankers \& Winterwerp, 2007; Winterwerp, 2002). Settling velocity of cohesive sediment is also greatly influenced by flocculation: The formation of large size flocs results in a settling velocity several orders of magnitude higher than individual particles (Van Leussen \& Cornelisse, 1993). Considering the importance of settling velocity in WSFM dynamics on the inner shelf (Harris et al., 2005), we designed two sensitivity tests using different sediment settling velocity in the WBL: (1) a constant (0.1 mm/s; red line in Figure 3) and (2) variable as a function of suspended sediment concentration which includes the effects of flocculation and hindered settling. Following Hwang (1989), Wolanski et al. (1989), and Sheremet et al. (2005), variable settling velocity is specified as 


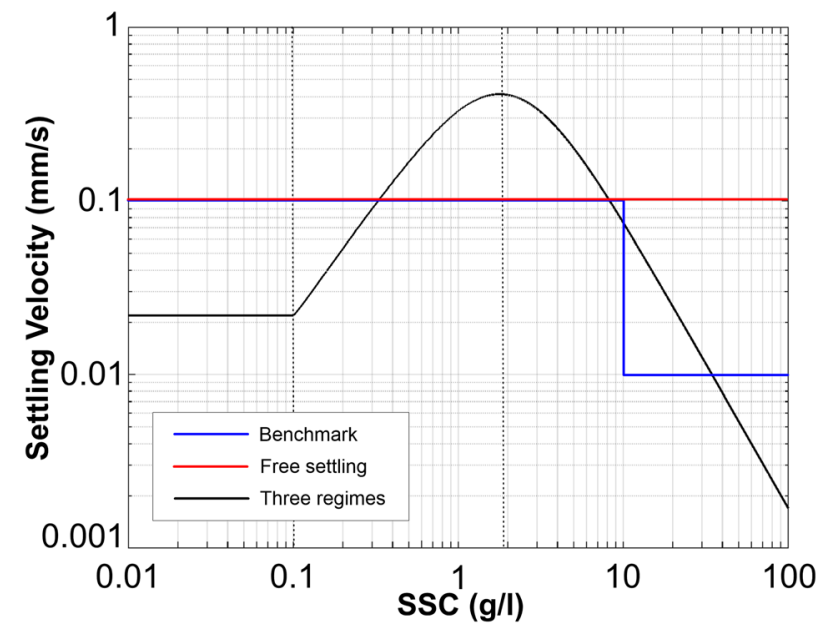

Figure 3. Relationships between sediment concentration and settling velocity in (1) benchmark run (blue), (2) free settling sensitivity test (red), and (3) three-regimes sensitivity test (black).

$$
w_{s, w b l}=\left\{\begin{array}{c}
w_{s f}\left(c_{s, w b l}<C 1\right) \\
a_{w} \frac{C^{1.33}}{\left(C^{2}+{ }^{2} C^{2}\right)^{1.5}}\left(c_{s, w b l} \geq C 1\right)
\end{array},\right.
$$

where $C 1$ is the sediment concentration threshold for particle interaction $(0.1 \mathrm{~g} / \mathrm{L})$. The curve of settling velocity variation with sediment concentration in the WBL $\left(c_{s, w b l}\right)$ is shown in Figure 3 (black line). When $c_{s, w b l}$ is lower than $C 1$, particle interaction is negligible, and settling velocity is equal to free settling velocity $\left(w_{s f}\right.$; $0.022 \mathrm{~mm} / \mathrm{s}$ ). If $c_{s, w b l}$ is higher than $C 1$, settling velocity goes up with the concentration due to the formation of flocs, and then it decreases with further increase of concentration as a result of hindered settling. $a_{w}$ is a dimensionless scaling coefficient (0.0037) and ${ }^{\sim} C$ is the hindered settling term $(2 \mathrm{~g} / \mathrm{L})$. As shown in Figure 3 , due to three different variations in settling velocity with increasing concentration, we will henceforth refer to the variable settling velocity as three-regimes settling velocity where these regimes correspond to free settling, enhanced settling due to flocculation, and hindered settling. The original CSTMS model uses a constant settling velocity for each sediment type, in our model the variable settling velocity formulations were applied only in the WBL cells, and $w_{s}$ was held constant in the overlying water grid cells $(0.1 \mathrm{~mm} / \mathrm{s})$.

Most sediment transport models adopted an user-specified constant critical shear stress $\left(\tau_{c r i}\right)$ to estimate seabed erosion (Caldwell \& Edmonds, 2014; Moriarty et al., 2015; Warner et al., 2008; Xu et al., 2011), while previous measurements recognized the increase of $\tau_{c r i}$ with burial depth for cohesive sediment deposits due to consolidation (Butman et al., 2014; Rinehimer et al., 2008; Sanford \& Maa, 2001; Xu, Bentley, et al., 2016). Sherwood et al. (2018) included this cohesive bed behavior into the CSTMS and tested its importance in sediment dynamics, stratigraphic evolution, and morphologic change. Given high mud content over the Atchafalaya shelf, we applied the cohesive bed behavior to the WSFM module and designed six $\tau_{c r i}$ vertical profiles (Table 1) with different slopes and surface critical shear stress $\tau_{\min }$ (Figures $4 \mathrm{a}$ and $4 \mathrm{~b}$ ). For these runs, the number of seabed layer was specified as 40 with a total thickness of $0.1 \mathrm{~m}$. The equilibrium $\tau_{\text {cri }}$ profile was specified as follows:

$$
\tau_{c r i}(k)=\min \left(\exp \left(\frac{\ln \left(M_{k-1}\right)-\tau_{\text {offset }}}{\tau_{\text {slope }}}\right), \tau_{\max }\right),
$$

where $\tau_{c r i}(k)$ is the bed critical shear stress in layer $k(2 \leq k \leq 40), M_{k-1}$ is the total bed mass from the top sediment layer to layer $k-1$, and $\tau_{\text {offset }}$ and $\tau_{\text {slope }}$ are constants. $\tau_{c r i}(k)$ is equal to $\tau_{\min }$ as $k=1$.

\section{Model Validation}

We quantitatively evaluated the performance of the coupled model by comparing model results with two in situ data sets collected over the Chenier Plain (Traykovski et al., 2015) and the Atchafalaya shelf (Sahin

Table 1

Cohesive Bed Parameterization

\begin{tabular}{lcccc}
\hline Test name & $\tau_{\text {min }}(\mathrm{Pa})$ & $\tau_{\max }(\mathrm{Pa})$ & $\tau_{\text {slope }}(\mathrm{Pa})$ & $\tau_{\text {offset }}(\mathrm{Pa})$ \\
\hline Cbed 1 & 0.08 & 2.5 & 2 & 8 \\
Cbed 2 & 0.08 & 2.5 & 2.5 & 6 \\
Cbed 3 & 0.08 & 2.5 & 2.5 & 5 \\
Cbed 4 & 0.03 & 2.5 & 2 & 8 \\
Cbed 5 & 0.03 & 2.5 & 2.5 & 6 \\
Cbed 6 & 0.03 & 2.5 & 2.5 & 5 \\
\hline
\end{tabular}

et al., 2012), both of which were tripod-based measurements (for locations of the observations see Figure 1). In Figure 5 we compared the simulated significant wave height (Figure 5a), wave bottom orbital velocity (Figure $5 \mathrm{~b}$ ) and normalized wave spectra (Figures $5 \mathrm{c}$ and $5 \mathrm{~d}$ ) with those measured off the Chenier Plain (T1 and T2). Three cold front-induced energetic events occurred on 4, 7, and 20 March 2008. Our model captured the sharply elevated significant wave height and wave bottom orbital velocity during the three cold fronts. The correlation coefficients $(R)$ were $0.89 / 0.91$ and $0.87 / 0.79$ for significant wave height/wave bottom orbital velocity at stations $\mathrm{T} 1$ 

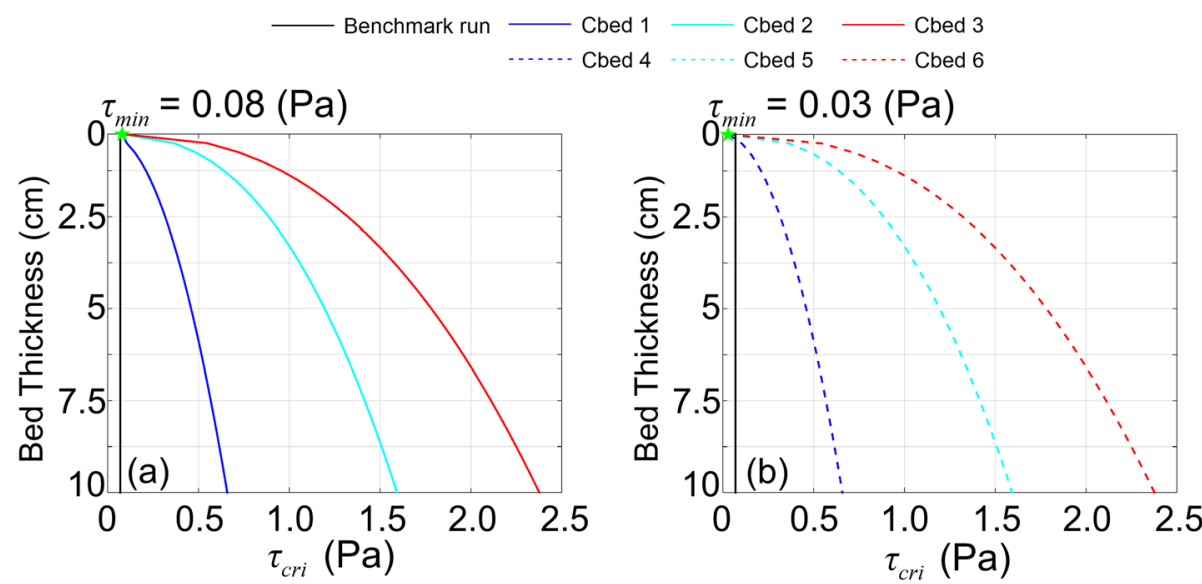

Figure 4. Equilibrium critical shear stress $\left(\tau_{c r i}\right)$ profiles. The black line represents $\tau_{c r i}=0.07(\mathrm{~Pa})$ in the benchmark run. The only difference between tests Cbed 1-3 a and Cbed 4-6 b is $\tau_{\min }$ (green star).

and T2, respectively. Both observed and simulated wave spectra (Figures $5 \mathrm{c}$ and $5 \mathrm{~d}$ ) exhibited high energy density during the three cold fronts. Higher energy in swell bands $(0.05 \mathrm{~Hz} \leq \mathrm{f} \leq 0.2 \mathrm{~Hz})$ suggested the importance of swell propagation in coastal Chenier Plain.

Simulated sediment concentration in the WBL over the Chenier Plain showed similar temporal pattern as Optical Backscattering Sensors (OBS) and Acoustic Backscattering Sensors (ABS)-based sediment measurements (Traykovski et al., 2015): When cold fronts approached, sediment concentration rose quickly from less than $1 \mathrm{~g} / \mathrm{L}$ to more than $10 \mathrm{~g} / \mathrm{L}$, indicating the formation of fluid mud during cold front events (Figure 6). After the passage of cold fronts, the decrease of sediment concentration due to sediment settling was also reproduced by our simulation.

As the field measurement of Sahin et al. (2012) was from 3-5 March, it only captured the hydro- and sediment dynamics during CF1. The significant wave height at T3 station increased from 0.5 to more than $1.0 \mathrm{~m}$ on $4 \mathrm{March}$, then decreased back to $0.5 \mathrm{~m}$ by the end of observation (Figure 7a). Our simulation in general reproduced the significant wave height variation $(R=0.74)$ although the simulated peak lags $10 \mathrm{hr}$. The difference could be ascribed to the relative coarse spatial resolution of the wind forcing used by our model (32 km). The salinity was stable ( 30 PSU) until 06:00:00 UTC 4 March, when freshwater was flushed out
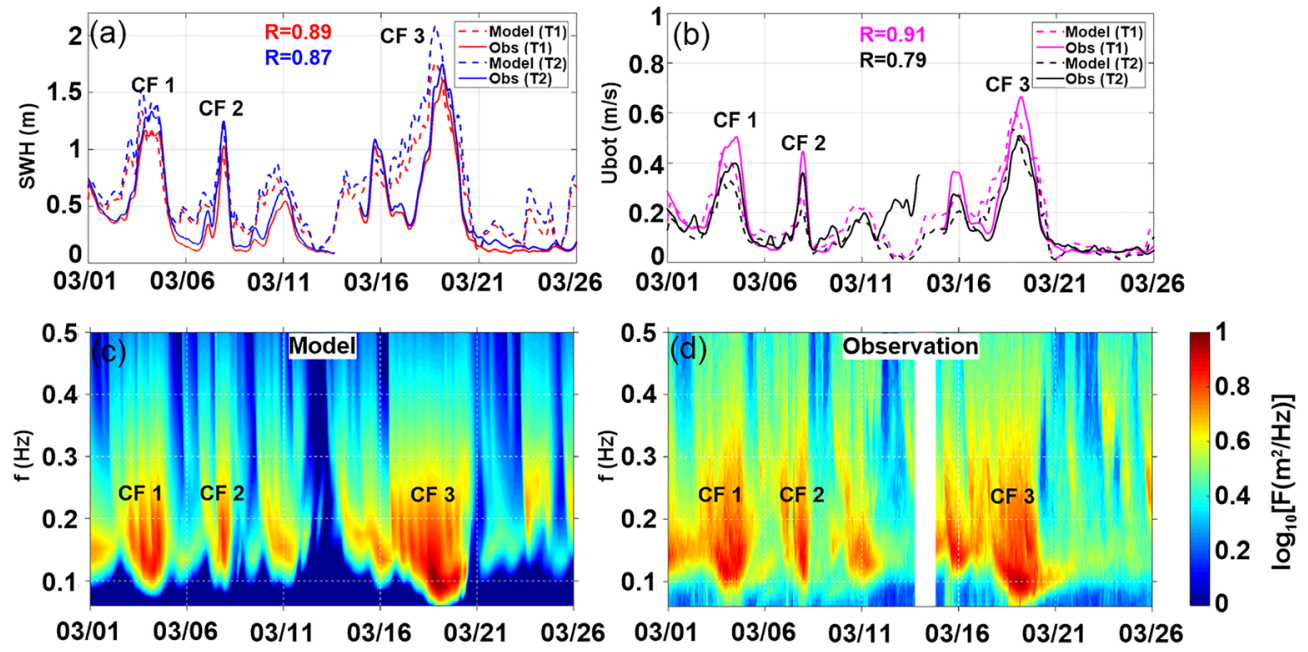

Figure 5. Comparisons of the observed and simulated significant wave height (a), wave bottom orbital velocity (b) at T1 and $\mathrm{T} 2$ stations, and wave spectra at T2 station (normalized between 0 and 1; c and d) with three labeled cold front events (CF1, CF2, and CF3). 


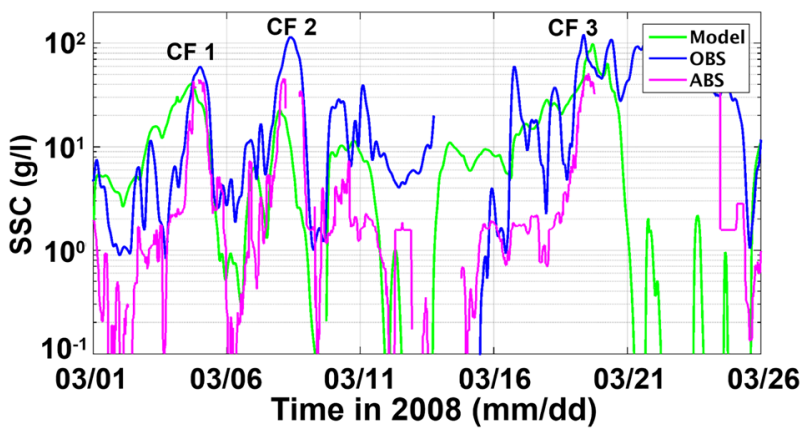

Figure 6. Comparisons of the observed (OBS and ABS at T1 station; Traykovski et al., 2015) and simulated sediment concentration in the wave boundary layer (WBL) with three labeled cold front events (CF1, CF2, and CF3). SSC measured by the OBS located at $25 \mathrm{~cm}$ above the foodpads. ABS measured sediment concentration over the lower $1 \mathrm{~m}$ of the water column.

of the bay as a result of the offshore expansion of the Atchafalaya River plume (Figure 7b). Depth-averaged (0-0.7 mab) current speed of southward and eastward flows increased to more than $40 \mathrm{~cm} / \mathrm{s}$ during cold front although our model underestimated eastward current speed after 06:00:00 UTC 4 March (Figure 7c). After CF1, salinity increased gradually due to freshwater plume landward retreat, and current speed declined to $\sim 0.2 \mathrm{~m} / \mathrm{s}$ (Figures $7 \mathrm{~b}$ and $7 \mathrm{c}$ ). Both modeled sediment concentration in the WBL and measured sediment concentration $18 \mathrm{cmab}$ increased during the waning phase of the cold front due to the offshore expansion of the sediment-laden river plume and sediment settling from the overlying water (Figure 7d). Sediment concentration reached its highest level after 12:00:00 UTC 4 March ( $>15 \mathrm{~g} / \mathrm{L}$ in the WBL) and decreased gradually after 18:00:00 UTC. However, the simulated sediment concentration peak $(40 \mathrm{~g} / \mathrm{L})$ was higher than the observation $(20 \mathrm{~g} / \mathrm{L})$, which could result in the overestimation of sediment flux. Overall, the comparisons between simulations and measurements confirmed that our model reproduced both the hydrodynamics and sediment dynamics during the passage of cold fronts, giving us the confidence that our model results could represent WSFM-related processes over the Atchafalaya shelf.

\section{Results}

\subsection{Winds, Hydrodynamics, and River Plume}

Since meteorological and hydrodynamic conditions varied drastically during cold front events, we specified two snapshots for each event representing precold front stage and cold front peak, respectively (Figures 8 and 9). Southeasterly wind prevailed the Atchafalaya shelf before the arrival of cold fronts, and significant wave height was less than $1.5 \mathrm{~m}$ (Figures $8 \mathrm{a}-8 \mathrm{c}$ ). Depth-averaged seaward current was $\sim 0.2 \mathrm{~m} / \mathrm{s}$ nearshore, and westward alongshore current dominated the shelf (Figures $8 \mathrm{~d}-8 \mathrm{f}$ ). Bottom shear stress $\left(\tau_{\mathrm{cw}}\right)$ was at low level because of calm hydrodynamic conditions (Figures $8 d-8 f$ ). The Atchafalaya River freshwater plume was mainly confined within 5-m isobath, and most freshwater was in the Atchafalaya Bay at precold front stage (Figures $8 \mathrm{~g}-8 \mathrm{i}$ ). When cold fronts swept across the shelf, wind direction became southeastward, and wind speed increased to more than $10 \mathrm{~m} / \mathrm{s}$ (Figures 9a-9c). Significant wave height decreased from $2.5 \mathrm{~m}$ offshore to $0.7 \mathrm{~m}$ nearshore (Figures 9a-9c). Current direction reversed to upcoast (eastward) due to the shift of

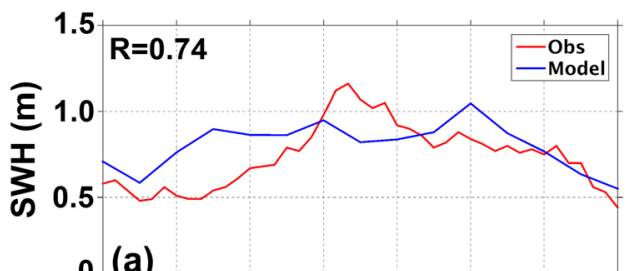

0 (a)

$03 / 0603 / 1203 / 1804 / 00 \quad 04 / 06 \quad 04 / 12 \quad 04 / 18 \quad 05 / 00$ Time in March 2008 (dd/hh)

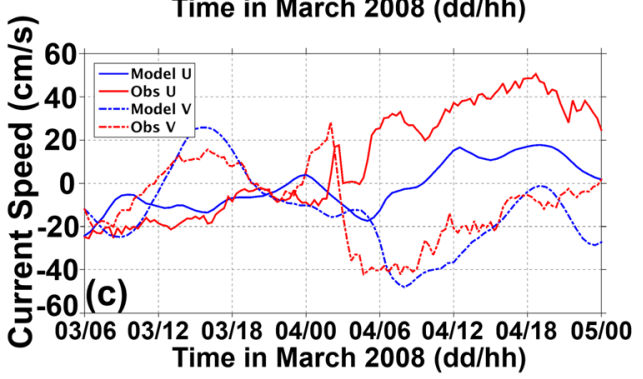

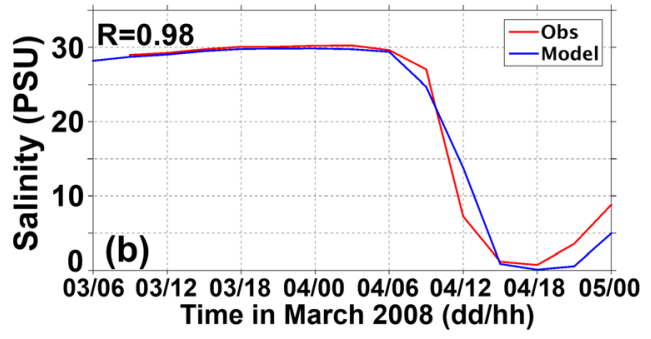

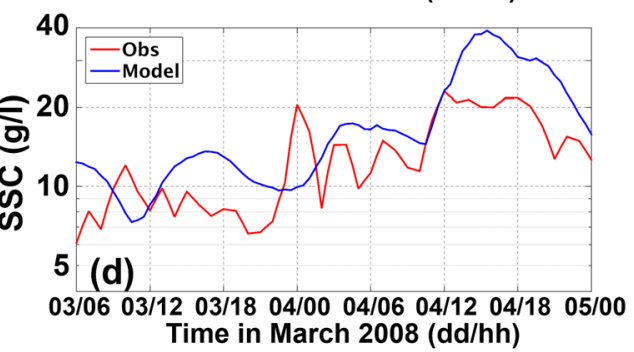

Figure 7. Comparisons of observed and modeled significant wave height (a), salinity (b), depth-averaged current field in east-west (u) and north-south (v) directions over 0-0.7 mab (c), and sediment concentration (d) in the WBL at T3 station. Current field was measured by PC-ADP, and SSC was measured by the OBS located at $18 \mathrm{cmab}$. 
(a) Pre-CF 1

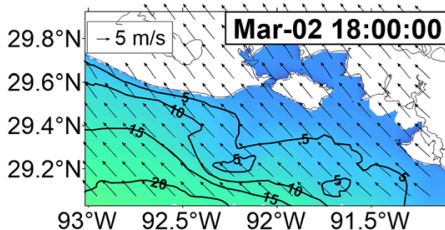

(d) Pre-CF 1

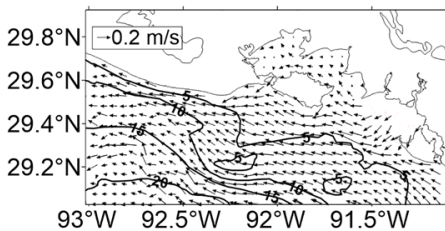

(g) Pre-CF 1

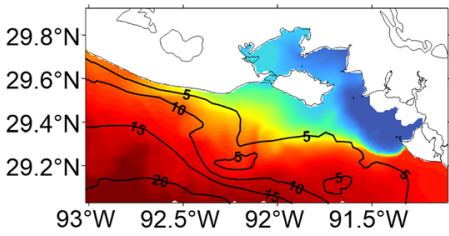

(b) Pre-CF 2

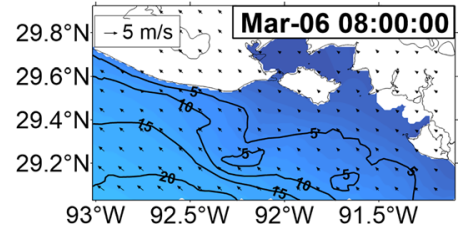

(e) Pre-CF 2

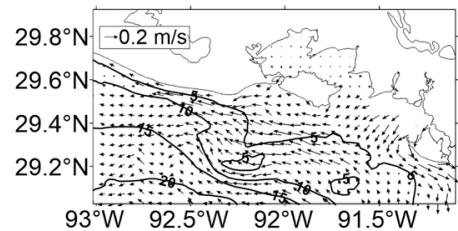

(h) Pre-CF 2

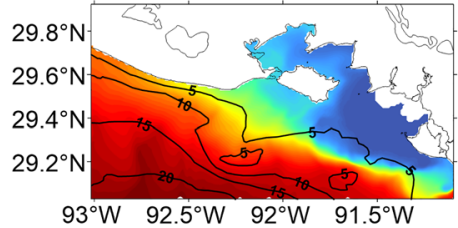

(c) Pre-CF $3 \quad$ Unit: $m$

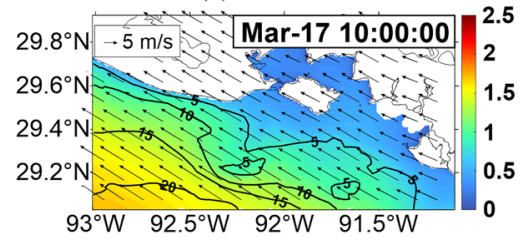

(f) Pre-CF 3

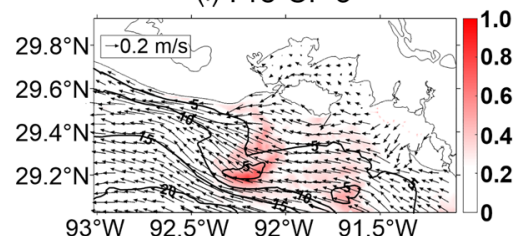

(i) Pre-CF 3

Unit: PSU

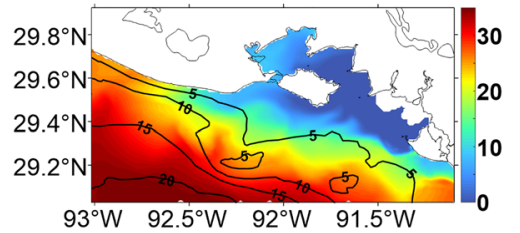

Figure 8. Wind field (arrow) and significant wave height (color) over the Atchafalaya shelf at three precold front stages (a-c). Current field (arrow) and bottom shear stress (color) at three precold front stages (d-f). Sea surface salinity at three precold front stages ( $\mathrm{g}-\mathrm{i}$ ). One column represents one cold front event, and the time is shown at upper right of panels a-c.

wind direction, and depth-averaged current speed went up to $\sim 0.6 \mathrm{~m} / \mathrm{s}$ off the Atchafalaya Bay (Figures 9d-9f). The maximum $\tau_{\mathrm{cw}}(>1.0 \mathrm{~Pa})$ was simulated between the $5-$ and $10-\mathrm{m}$ isobaths (Figures 9d-9f). The upcoast flow over the shelf resulted in eastward expansion of freshwater plume while the offshore expansion was quite limited (Figures 9g-9i). After the passage of cold fronts, both wind field and hydrodynamics returned to normal conditions.

(a) Peak CF 1

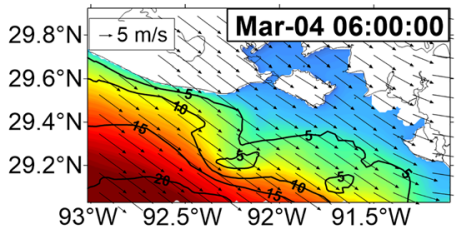

(d) Peak CF 1

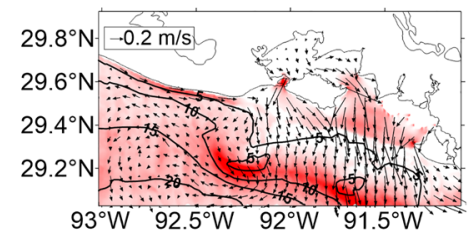

(g) Peak CF 1

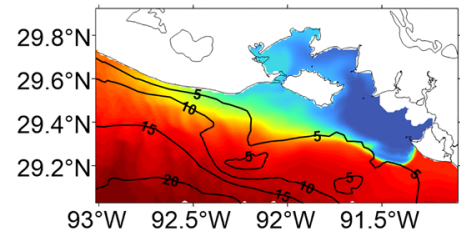

(b) Peak CF 2

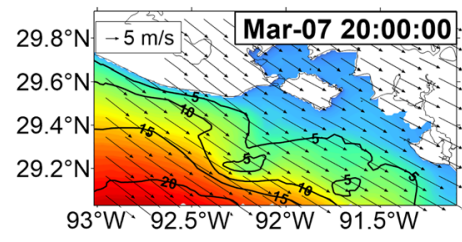

(e) Peak CF 2

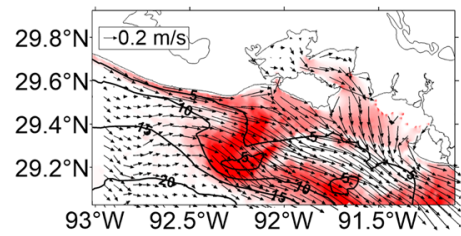

(h) Peak CF 2

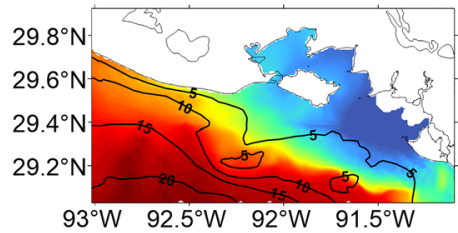

(c) Peak CF $3 \quad$ Unit: $m$

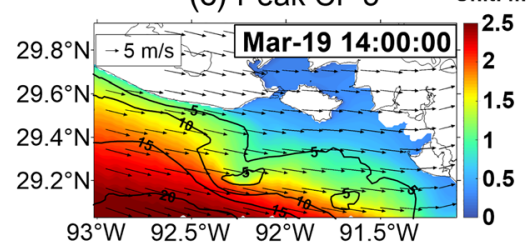

(f) Peak CF 3

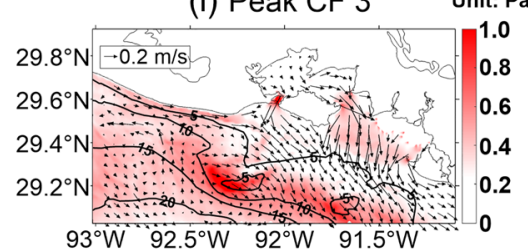

(i) Peak CF 3

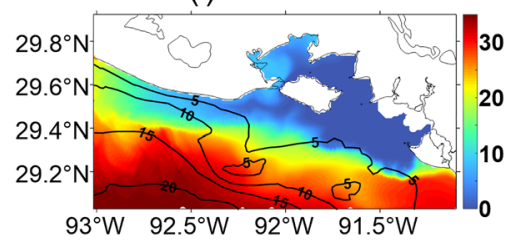

Figure 9. Same as Figure 8 but at peak stages of three cold fronts. The time is shown at upper right of panels a-c. 
(a) CF 1

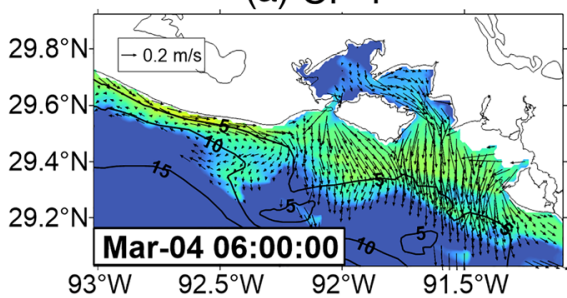

(c) $\mathrm{CF} 2$

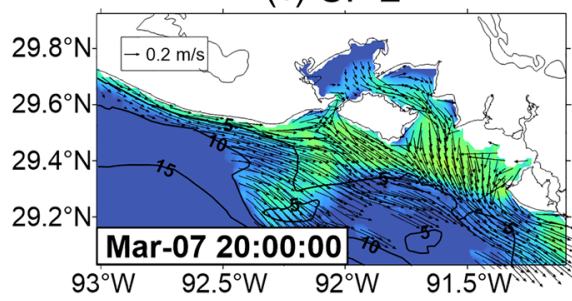

(e) $\mathrm{CF} 3$

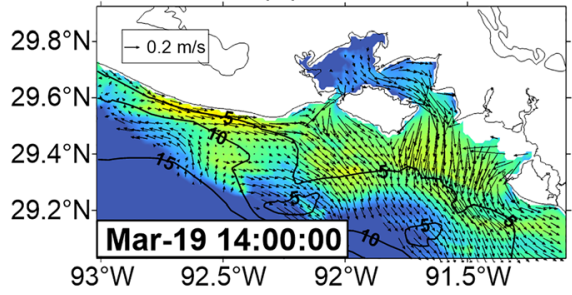

(b) CF 1

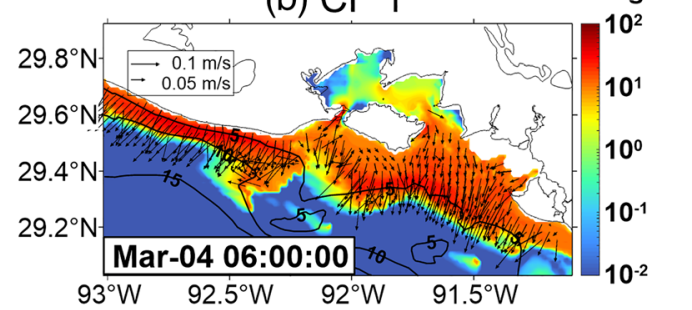

(d) $\mathrm{CF} 2$
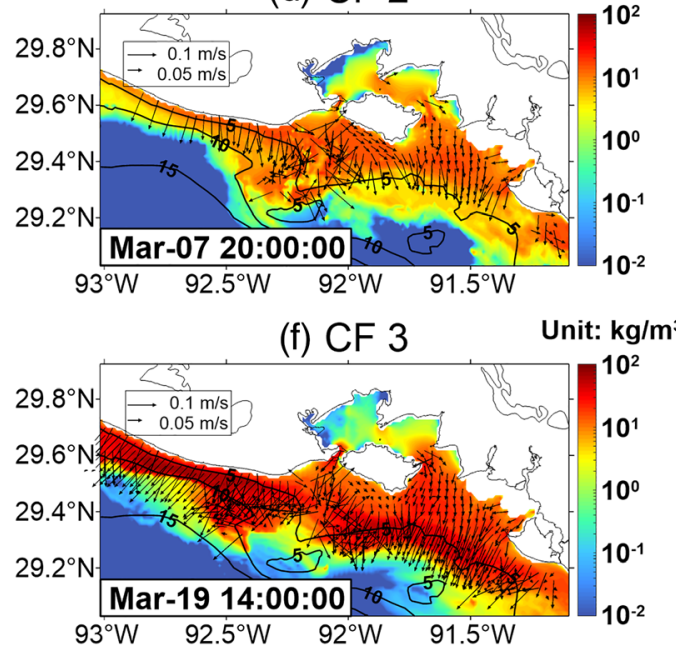

Figure 10. Depth-averaged current velocity (indicated with arrows; left panel) in the water column and WSFM velocity (indicated with arrows; right panel) overlain with depth-averaged SSC (color; left panel) and WSFM concentration (color; right panel) when cold fronts approached. Each row represents one cold front event (CF1, CF2, and CF3). To highlight sediment transport direction, we only plotted velocity arrow where SSC >10 mg/L in the left panel and WSFM concentration $>10 \mathrm{~g} / \mathrm{L}$ in the right panel.

\subsection{Sediment Dispersal}

When fluid mud formed during the passage of cold fronts, sediment concentration in the WBL was on the order of 10-100 g/L, which was more than 10 times higher than the depth-averaged SSC in the overlying water column (Figure 10). Both SSC in the water column and sediment concentration in the WBL were determined by the strength of wave activities (CF3 > CF1 > CF2). The seaward boundaries of simulated WSFM were located between 5- and $15-\mathrm{m}$ isobaths. Velocity of WSFM ranged from $3 \mathrm{~cm} / \mathrm{s}$ in the Atchafalaya Bay to $12 \mathrm{~cm} / \mathrm{s}$ off the bay mouth and Chenier Plain coast (Figure 10). Since WSFM motion was mainly driven by the downslope gravitational force, its direction aligned with the downslope gravitational force over the shelf as well (Figure 10). For suspended sediments in the water column, currents determined the intensity and direction of transport: Prevailing seaward currents delivered large amounts of sediments out of the bay, while the eastward alongshore transport dominated the Atchafalaya shelf and seaward transport became very weak. Compared with the westward fluvial sediment transport under normal weather conditions (Kolker et al., 2014; Walker \& Hammack, 2000), when cold fronts impacted the shelf, the suspended sediment transport direction was toward the east. Thus, rather than the direct Atchafalaya fluvial sediment delivery, suspended sediments off the Chenier Plain were from the resuspension of modern sediment deposits, and exposed relict sediment deposits formed during the activity of the Lafourche delta lobe ( 1,200-600 years BP; Törnqvist et al., 1996).

To quantitatively evaluate the contributions of suspended sediment transport and WSFM transport to sediment dispersal off the Chenier Plain and Atchafalaya Bay, we estimated suspended sediment flux (SSF) and WSFM flux in alongshore and cross-shore directions at T1 and T3 stations. For clarification, it is worth distinguishing SSF defined in previous studies and that herein: Here SSF refers to dilute sediment flux in the 
(a) alongshore sediment flux at T1

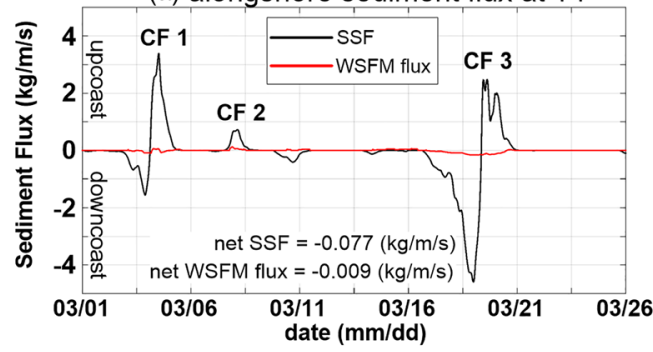

(c) across-shore sediment flux at T1

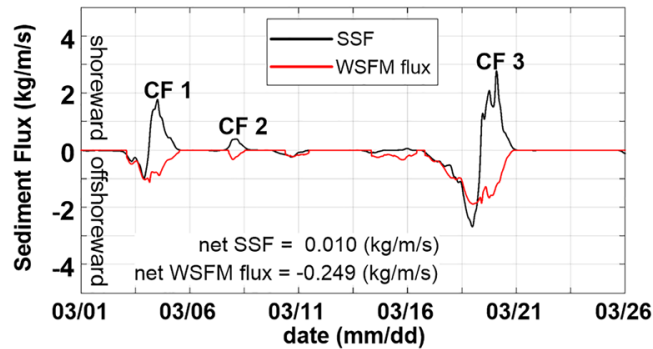

(b) alongshore sediment flux at T3

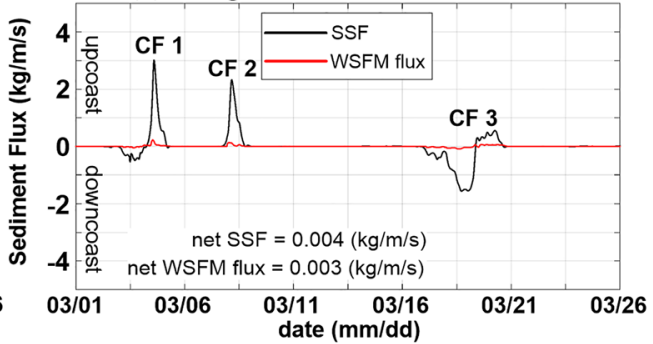

(d) across-shore sediment flux at T3

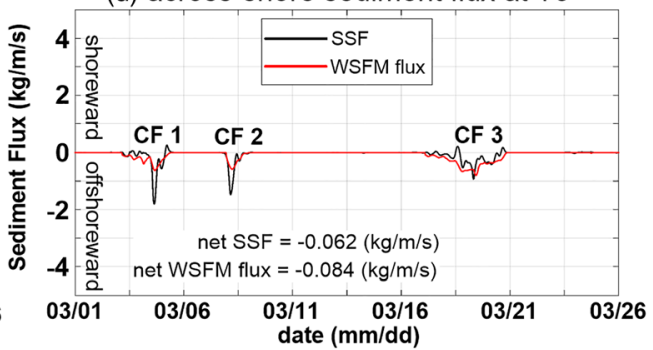

Figure 11. Time series of alongshore and cross-shore sediment fluxes (black: SSF; red: WSFM flux) at T1 (a and c) and T3 (b and d) stations with three labeled cold front events (CF1, CF2, and CF3). For alongshore sediment flux, positive value represents upcoast direction (oriented $60^{\circ}$ east of south) and negative value represents downcoast direction (oriented $60^{\circ}$ west of north). For cross-shore sediment flux, positive value represents shoreward direction (oriented $30^{\circ}$ east of north) and negative value represents offshoreward direction (oriented $30^{\circ}$ west of south).

water column excluding WSFM flux in the WBL. Under quiescent condition, sediment flux was negligible until cold fronts approached (Figure 11). At T1 station, alongshore SSF $(0.077 \mathrm{~kg} / \mathrm{m} / \mathrm{s})$ outweighed alongshore WSFM flux (0.009 kg/m/s; Figure 11a). In seaward direction, however, across-shelf WSFM flux reached $0.249 \mathrm{~kg} / \mathrm{m} / \mathrm{s}$, which was more than 20 times higher than across-shelf SSF $(0.01 \mathrm{~kg} / \mathrm{m} / \mathrm{s}$; Figure 11c). For T3 station, net SSF $(0.062 \mathrm{~kg} / \mathrm{m} / \mathrm{s})$ and WSFM flux $(0.084 \mathrm{~kg} / \mathrm{m} / \mathrm{s})$ in seaward direction (Figure 11d) were comparable, and they were an order of magnitude higher than those in alongshore direction (SSF: $0.004 \mathrm{~kg} / \mathrm{m} / \mathrm{s}$; WSFM flux: $0.003 \mathrm{~kg} / \mathrm{m} / \mathrm{s}$; Figure 11b). Overall, WSFM flux did not contribute significantly to the alongshore transport but was a key component of the across-shelf (seaward) transport (Figure 11). Unlike WSFM transport, the direction of SSF varied greatly during the cold front events due to the rapid change of wind direction, and net SSF shifted from seaward off the Atchafalaya Bay (T3 station) to alongshore direction off the Chenier Plain (T1 station).

\subsection{Comparison Between CSTMS and CSTMS + WBL Model}

\subsubsection{Vertical Structure}

To reveal the difference of sediment vertical structure brought by WSFM-related processes, we extracted model results along two cross-shore transects (Figures 12 and 13, locations see Figure 1a): one across the tripod over the Atchafalaya shelf (Transect A) and the other across the tripods off the coastal Chenier Plain (Transect B). The maximum water depth of both transects was set to $10 \mathrm{~m}$, and their directions were perpendicular to the coastline.

With WSFM module, the horizontal distribution of suspended sediment in the water column was similar to that of the original CSTMS run: SSC was highest nearshore, and it decreased gradually seaward. The vertical gradient of SSC was trivial in shallow area, and it became stronger offshore because the deep water was not as well mixed as the shallow water. However, including WSFM module weakened sediment resuspension, and the SSC was lower. The only exception was the SSC along transect B during CF3 (Figures 13e and 13f). The resuspension intensity difference could be explained by different sediment erosion algorithms between the original CSTMS and WSFM module (Equations 1 and 2). Besides, the two sediment models employed different algorithms to estimate sediment resuspension into the bottommost water layer. In the original CSTMS, upward sediment flux into water is equal to sediment resuspension flux (Equation 1). The WSFM module, however, quantifies upward sediment flux ( $E_{w b l}$ in Equation 3) based on wave 
(a) CF 1 (CSTMS)

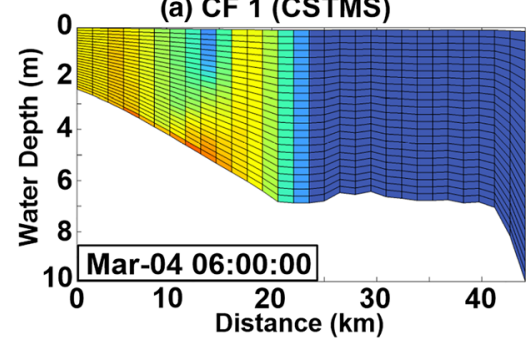

(c) CF 2 (CSTMS)

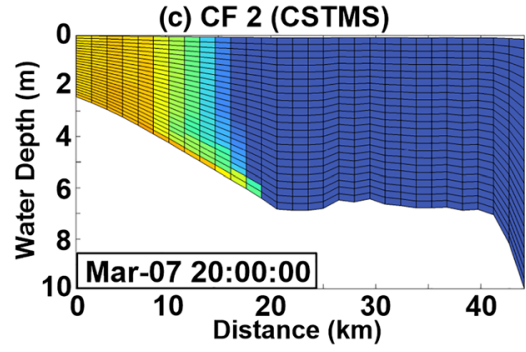

(e) CF 3 (CSTMS)

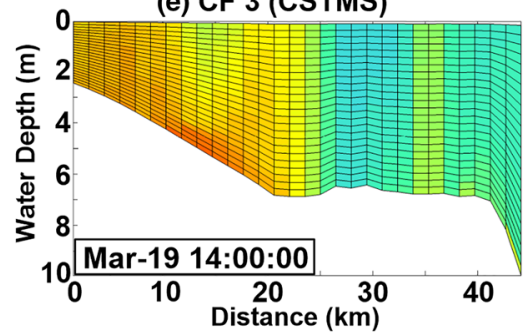

(b) CF 1 (CSTMS + WBL)

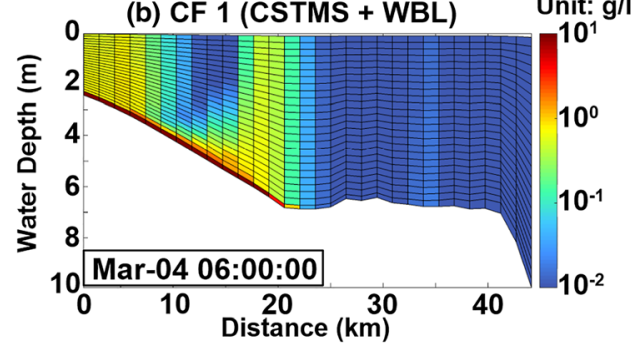

(d) CF 2 (CSTMS + WBL)
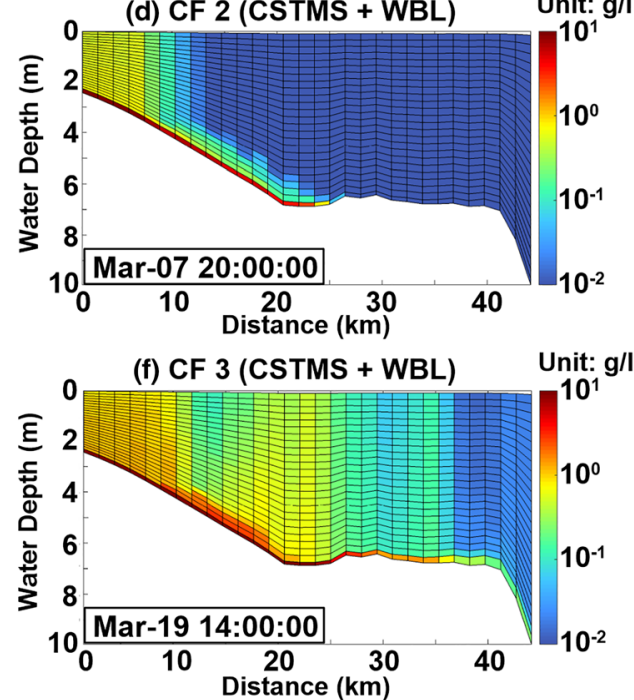

Figure 12. Vertical distributions of SSC along Transect A during the passages of three cold fronts with (right panel) and without (left panel) the WBL. Each row represents one cold front. The WBL grid is the bottom cell on the right panel.

dynamics and intensity of vertical stratification (Munk \& Anderson, 1948; Ross \& Mehta, 1989). The most significant difference between the two simulations appeared at the bottom: A lutocline developed between the WBL and the bottom water layer in the benchmark run. Sediment concentration in the WBL reached more than $10 \mathrm{~g} / \mathrm{L}$, and $\mathrm{SSC}$ in the bottom water layer ranged from $5 \mathrm{~g} / \mathrm{L}$ at the bottom nearshore to almost zero offshore (right panels of Figures 12 and 13). The original CSTMS, however, could not resolve the formation of fluid mud in the WBL and lutocline (left panels of Figures 12 and 13).

\subsubsection{Sediment Flux and Erosion/Deposition Pattern}

Figure 14 compares the temporal-averaged sediment flux (SSF and WSFM flux) of the benchmark case $(\mathrm{CSTMS}+\mathrm{WBL})$ to that of the original CSTMS run. Between the two simulations, the directions of SSFs were similar (seaward off the Atchafalaya Bay and northwestward along the coast of Chenier Plain), while the original CSTMS run reproduced higher SSF off the Atchafalaya Bay and Chenier Plain due to more sediment was entrained into the water column (Figures 14a and 14b). Seaward WSFM flux in the benchmark run was comparable with SSF off the Atchafalaya Bay mouth $(\sim 0.1 \mathrm{~kg} / \mathrm{m} / \mathrm{s})$. However, WSFM flux $(\sim 0.4 \mathrm{~kg} / \mathrm{m} / \mathrm{s})$ overwhelmed SSF $(<0.1 \mathrm{~kg} / \mathrm{m} / \mathrm{s})$ along the Chenier Plain coast due to strong wave activities (Figures 14b and 14c).

The most distinguished difference of erosion/deposition between the two simulations distributed along the Chenier Plain (Figure 15). When WSFM transport was excluded, both net erosion and deposition over the coastal Chenier Plain were less than $2 \mathrm{~cm}$ (Figure 15a). With WSFM included, strong seaward fluid mud transport resulted in severe onshore erosion $(>4 \mathrm{~cm})$ and thick offshore deposition located onshore of $10-\mathrm{m}$ isobath (Figure 15b), which was consistent with measurements of accumulation rate off the Chenier Plain (Denommee et al., 2018; Rotondo \& Bentley, 2003). Another notable difference of erosion/deposition between the two simulations was found at the Atchafalaya Bay mouth: Although both benchmark and original CSTMS runs reproduced net erosion in the Atchafalaya Bay and offshore net 

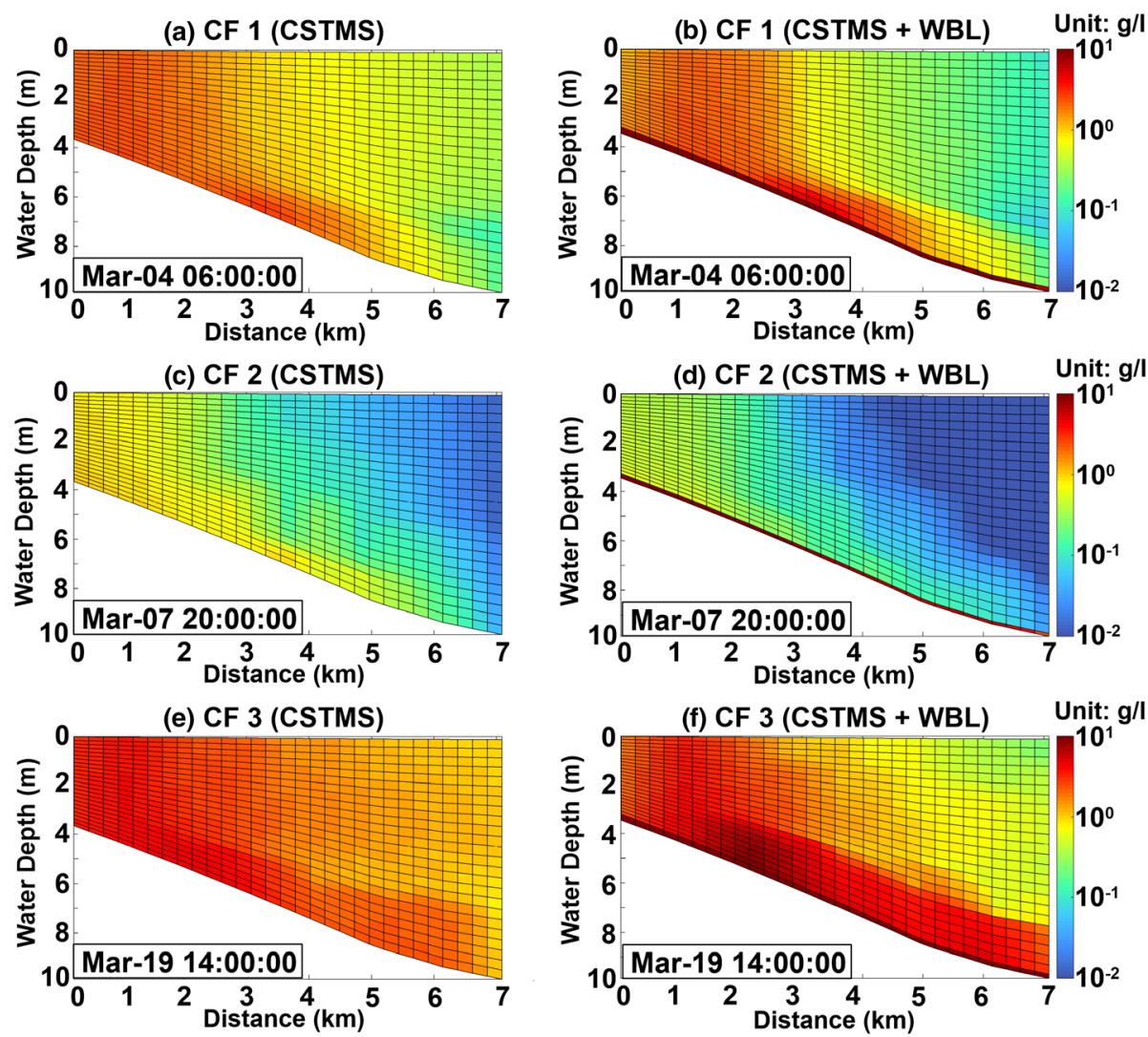

Figure 13. Same as Figure 12 but along Transect B. The WBL grid is the bottom cell on the right panel.

deposition (Figure 15), the area of net erosion in the Atchafalaya Bay was larger, and an elongated net deposition was formed along the 5-m isobath in the benchmark run (Figure 15). Compared with the Atchafalaya shelf off the bay mouth, the steeper bathymetry of the Chenier Plain (Figure 1) and higher wave energy (Figures 9d-9f) increased the downslope momentum of WSFM transport. Both reasons resulted in the stronger WSFM dynamics off the Chenier Plain than that at the Atchafalaya Bay mouth.

\section{Discussion}

In this section we discuss the importance of WSFM in the depositional settings, our WSFM model's response to fluvial supply variation, settling velocity parameterization, and cohesive bed behavior (see section 2.3 for detailed method and setup of sensitivity tests), followed by a discussion of model uncertainty.

\subsection{The Role of Fluid Mud in the Depositional Settings}

Although the WSFM only forms during short-term events (i.e., cold fronts and hurricanes; Kineke et al., 2006; Sheremet et al., 2005), high sediment flux associated with WSFM downslope transport contributes to the long-term depositional environments over the Atchafalaya shelf: ${ }^{210} \mathrm{~Pb}$ chronological results of Allison et al. (2000) and Neill and Allison (2005) revealed higher deposition rate at the Atchafalaya Bay mouth, which was consistent with the elongated offshore depo-center simulated in the benchmark run. Although our simulation and ${ }^{210} \mathrm{~Pb}$ results were not quantitatively comparable since they focused on different temporal scales (model: 25 days; ${ }^{210} \mathrm{~Pb}$ : several decades), the similar location and morphology of offshore deposition implies the potential importance of WSFM in terms of cross-shore transport and offshore depo-center formation on decadal scales. For the ROFI of other rivers (e.g., Yellow River, Amazon River, Rhone River, and Waipaoa River) where fluid mud was observed, long-term variation of water depth and ${ }^{210} \mathrm{~Pb}$ chronological results also suggested the existence of offshore depo-center (Kuehl et al., 1986; Miller \& Kuehl, 2010; Radakovitch et al., 1999; Wang et al., 2006). Since fluid mud needs to be supported by high velocity shear 
(a) SSF (CSTMS)
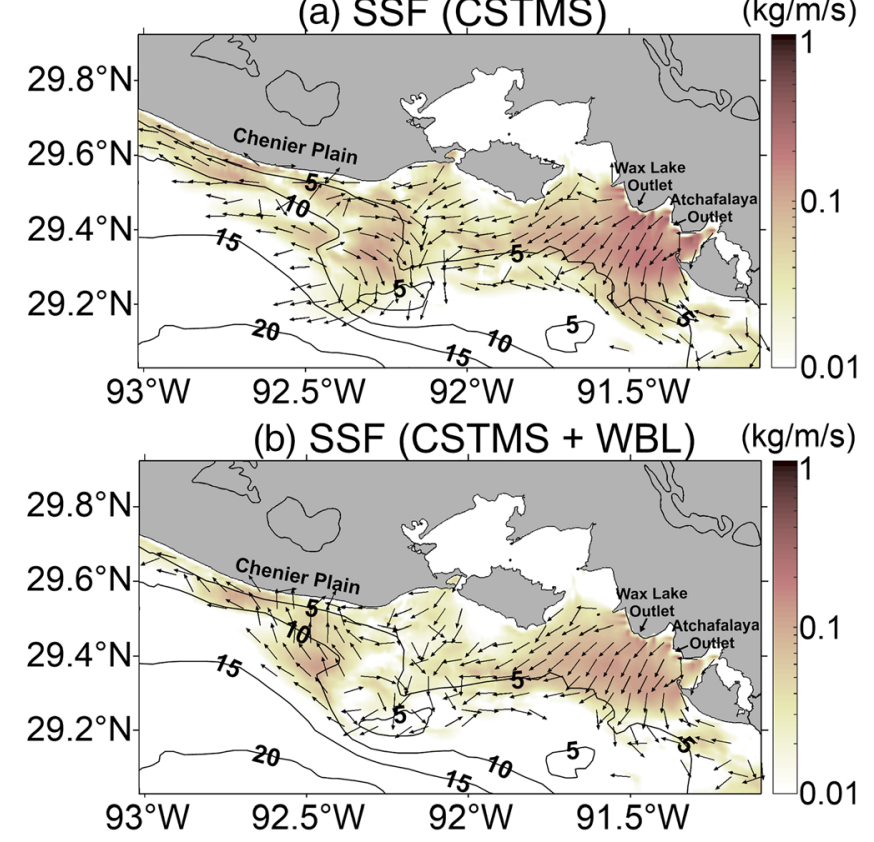

(c) WSFM flux (CSTMS + WBL) $(\mathrm{kg} / \mathrm{m} / \mathrm{s})$

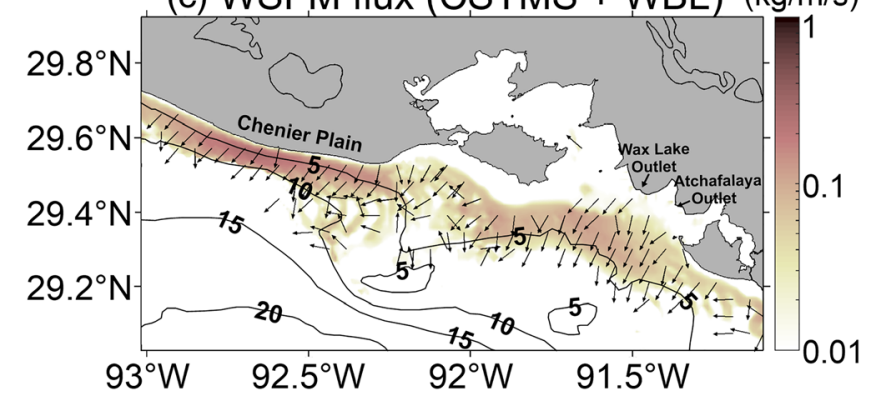

Figure 14. Temporal-averaged (25 days) SSF in the water column based on original CSTMS model (a) and CSTMS + WBL model (b) and WSFM flux based on CSTMS + WBL model (c). The arrows indicate sediment flux direction and background color represents sediment flux. due to bottom wave orbital velocity or current, deposition associated with fluid mud transport only distributes on the shelf where water depth is less than $200 \mathrm{~m}$. Given the ubiquity of fluid mud and its importance in sediment transport from event to decadal scales, a better understanding of fluid mud dynamics is of importance in exploring the morphological evolution and quantifying net cross-shelf sediment flux in the ROFI.

\subsection{Sensitivity to Riverine Sediment Supply}

We compared our benchmark run results with sensitivity tests based on different riverine sediment inputs to reveal the importance of fluvial sediment discharge to sediment dynamics over the Atchafalaya shelf. As shown in Figures 16a and 16b, the erosion/deposition difference introduced by riverine sediment discharge variation was only evident within the Atchafalaya Bay. The differences in seabed thickness (Figures 16a and 16b) and sediment fluxes (both SSF and WSFM flux; Figures 16c-16f) maximized off the two outlets (Wax Lake outlet and Atchafalaya outlet) of the Atchafalaya River and decreased seaward. Unlike the Eel River shelf where sediment flux and deposition vary greatly with flood magnitude (Harris et al., 2005), the Atchafalaya shelf is shallow and gentle, and the river plume is largely constrained in the semi-enclosed bay. Thus, the influence of riverine sediment input is highly localized in the Atchafalaya Bay, and the shelf can hardly be directly affected by fluvial sediment discharge variation. ${ }^{7}$ Be derived deposition rate in different years' flood season also indicated that deposition rate around the Atchafalaya Bay was highly correlated with the magnitude of floods, while for the offshore area (water depth $>15 \mathrm{~m}$ ), there is no clear correlation between high river discharge during flood season and cross-shore sediment transport (Allison et al., 2000; Kolker et al., 2014). Besides, several sediment cores collected off the Chenier Plain had $4 \mathrm{~cm}$ thick fluid mud layer that did not contain ${ }^{7} \mathrm{Be}$ (Rotondo \& Bentley, 2003). The thick fluid mud layer without excess ${ }^{7}$ Be activity indicated that WSFM transport was still dominant with little deposition of freshly discharged fluvial sediments along the Chenier Plain. Therefore, WSFM downslope movement over the Atchafalaya shelf is limited by transport intensity rather than modern fluvial sediment supply. The Atchafalaya River fluvial sediment input mainly influences the sediment dynamics in the Atchafalaya Bay, and fluvial impact becomes less important with the increase of distance to the Atchafalaya River outlets.

\subsection{Sensitivity to Settling Velocity}

To quantitatively evaluate the influence of sediment settling velocity, we compared the erosion/deposition patterns between the benchmark run and the sensitivity tests that used constant settling velocity (free settling) and dynamic settling velocity with hindered settling effect and flocculation (see section 2.3 for details). The three experiments used identical setup except the settling velocity schemes in the WBL.

Net erosion/deposition patterns based on constant settling velocity (Figure 17a) and three-regimes settling velocity (Figure 17b) were similar to the benchmark run (Figure 15b). However, the thickness of net erosion/deposition in the two sensitivity tests was different from that of the benchmark run. Here we estimated the erosion/deposition difference between the benchmark run and sensitivity tests with different settling velocity schemes (Figures 17c and 17d). In free settling case, both nearshore erosion and offshore deposition were thinner compared with the benchmark run (blue color nearshore and red color offshore in Figure 17c), suggesting that the calculated seaward sediment flux was increased by the hindered settling effect. When three-regimes settling velocity was specified, onshore erosion and offshore deposition were thicker compared with the benchmark run (red nearshore and blue offshore areas in Figure 17d). Such 
(a) CSTMS

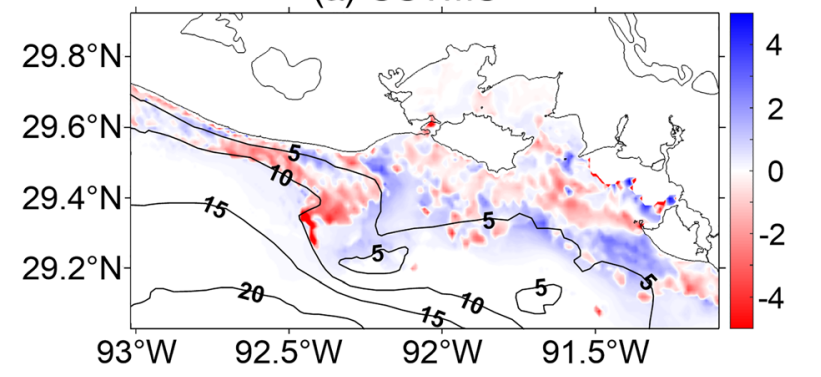

(b) CSTMS + WBL

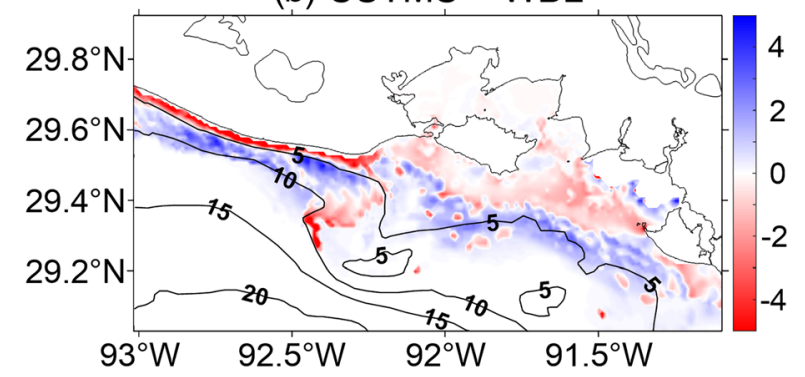

Figure 15. Net erosion (red) and deposition (blue) pattern based on original CSTMS model (a) and CSTMS + WBL model (b). difference indicates that seaward transport became stronger once hindered settling effect was included (both benchmark run and three-regimes settling velocity case). The reason for the intensified seaward transport once hindered settling becomes effective is that sediments remain in suspension in the WBL longer due to slower settling velocity and hence delays their deposition to the seafloor. Besides, higher sediment concentration in the WBL induced by hindered settling enhances downslope component of gravitational force in the WBL, which can increase seaward WSFM flux effectively (Harris et al., 2005). The flocculation regime, however, does not affect WSFM dynamics too much because the increase of WSFM concentration during cold front is sharp, and the flocculation regime does not have enough time to post substantial impact on sediment settling. Since most studies included flocculation in the idealized sediment transport models (Liu et al., 2019; Maerz et al., 2011; Shen \& Maa, 2016; Xu et al., 2010), it is still a challenge to evaluate the role of flocculation in realistic depositional settings. Tarpley et al. (2019) implemented flocculation formulation within an idealized estuary domain and found sediment concentration in the water column halved in the estuarine turbidity maximum (ETM) region due to settling acceleration. Compared with high density of fluid mud, sediment concentration in the ETM is on the order of $0.2-2.0 \mathrm{~g} / \mathrm{L}$ (McSweeney et al., 2017; Olabarrieta et al., 2018; Sanford et al., 2001), in which flocculation exerts a great influence on sediment settling velocity (Figure 3). Although our sensitivity tests suggest the impact of flocculation is quite limited in the WBL, flocculation can affect sediment settling velocity in the water column and modulate sediment concentration in the WBL via changing sediment settling flux from the bottom water layer into the WBL. To comprehensively estimate the influence of flocculation on WSFM, flocculation-induced sediment settling velocity variation in the water column should be taken into account in future model studies.

\subsection{Sensitivity to Cohesive Bed Behavior}

We compared simulated sediment concentration in the WBL at T1 station between the benchmark run and six sensitivity tests (Cbed 1-6) to evaluate the significance of cohesive bed behavior in WSFM dynamics. For the tests with $\tau_{\text {min }}=0.08 \mathrm{~Pa}$ (Cbed 1-3), the concentration was lower than the benchmark run due to higher $\tau_{c r i}$ in each layer (solid curves in Figure 18). The results showed that including cohesive bed behavior did not change sediment concentration in the WBL significantly during CF1, while the concentration difference turned to be more dominant during $\mathrm{CF} 2$ and $\mathrm{CF}$. The greater sediment concentration difference during $\mathrm{CF} 2$ and $\mathrm{CF} 3$ suggested the importance of sediment consolidation in WSFM dynamics: After several rounds of erosion, the seabed became more erosion-resistant, and sediment resuspension was weaker in the following erosion events. Similar findings were also reported based on the observations on the Eel shelf (Traykovski et al., 2007). Interestingly, observations of Traykovski et al. (2015) in the nGoM indicated sediment concentration in the WBL were more related to the intensity of cold front events rather than seabed consolidation (Figure 6). There are three possible reasons that might explain why cohesive bed behavior was less important than cold front intensity in observations off the Chenier Plain (Traykovski et al., 2015): (1) Coastal erosion and alongshore suspended sediment transport provided extra easily erodible cohesive sediments to the measurement site (Draut, Kineke, Huh, et al., 2005); (2) the surface fluffy seabed layer with small $\tau_{c r i}$ over the Atchafalaya shelf was thicker than the maximum erosional depth, and the underlying erosion-resistant layer was not exposed to the bottommost water layer during cold front-induced erosion; and (3) the parameterization of the swelling and consolidation timescales might partially explain the discrepancies between model and measurements.

As we decreased $\tau_{\min }$ to $0.03 \mathrm{~Pa}$ (Cbed 4-6; Table 1), the temporal variation of sediment concentration in the WBL changed dramatically: Sediment concentration was overestimated under normal conditions and underestimated when a cold front approached (dashed curves in Figure 18). During CF1 and CF3, 

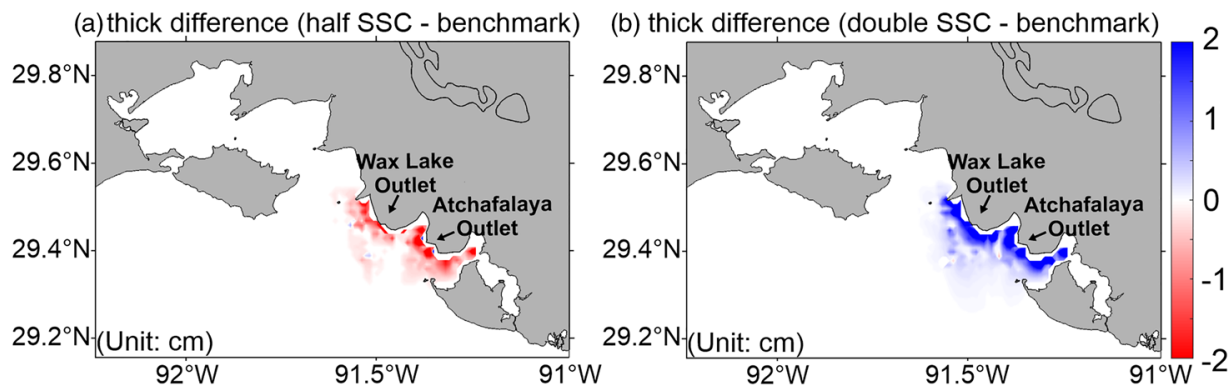

(c) SSF difference (benchmark and half SSC)
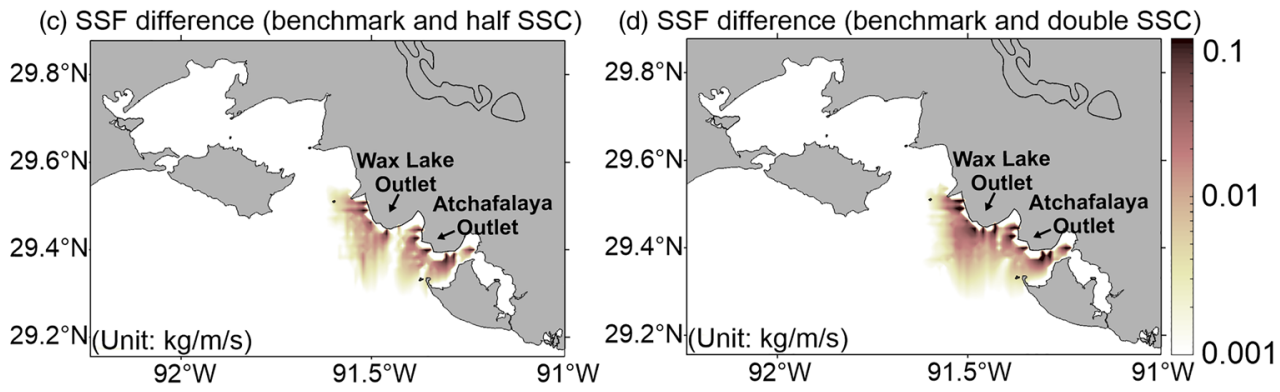

(e) WSFM flux difference (benchmark and half SSC) (f) WSFM flux difference (benchmark and double SSC)
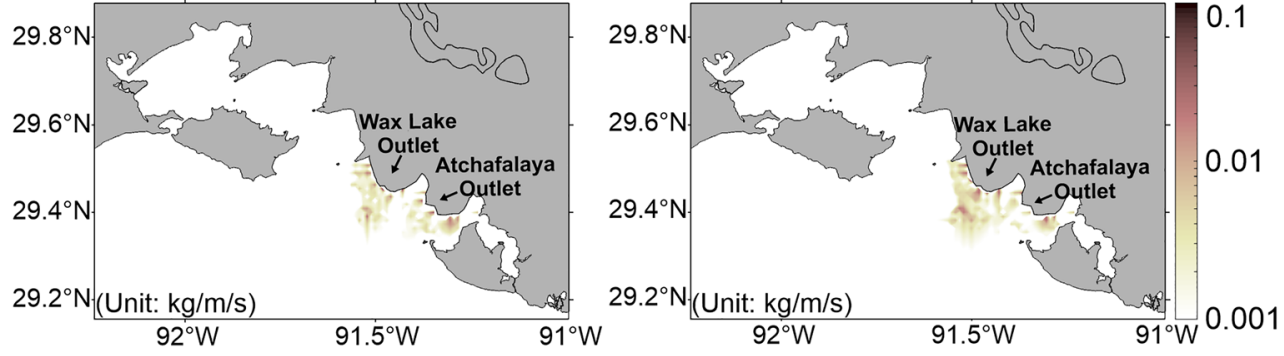

Figure 16. The difference of seabed thickness ( $a$ and b), SSF in the water column (c and d), and WSFM flux in the WBL (e and f) between benchmark run and sensitivity tests whose fluvial sediment concentration is halved (left panel) or doubled (right panel).

sediment concentration was even lower than the tests with $\tau_{\min }=0.08 \mathrm{~Pa}$ because overestimated erosion before cold fronts exposed the seabed layers with a higher $\tau_{c r i}$. Dramatic sediment concentration

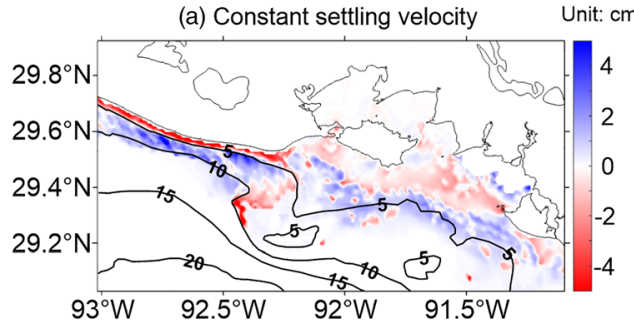

(c) thick difference (constant - benchmark) Unit: $\mathrm{cm}$

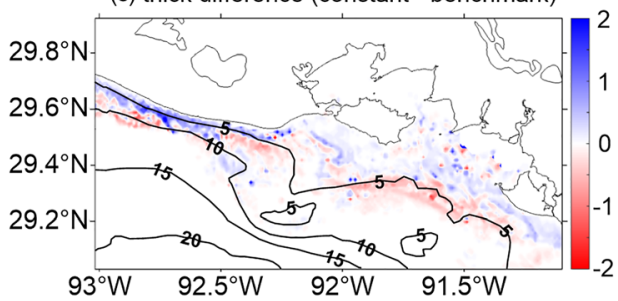

(b) Three regimes settling velocity

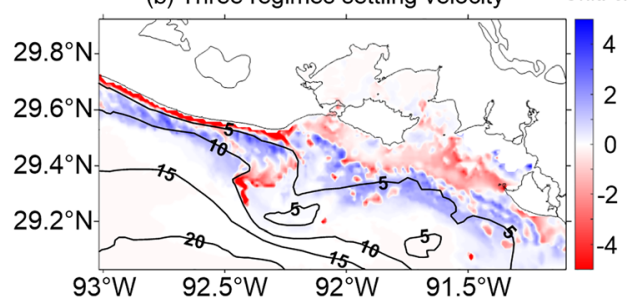

(d) thick difference (three regimes - benchmark) Unit: $\mathrm{cm}$

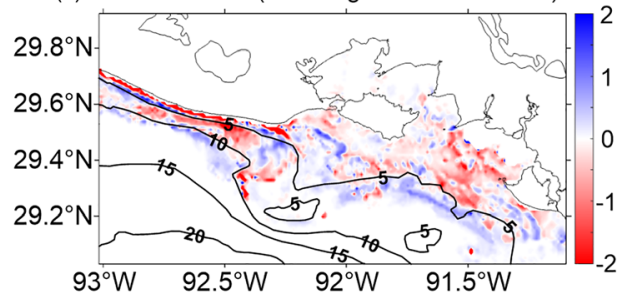

Figure 17. Net erosion/deposition patterns based on constant settling velocity (a) and three-regimes settling velocity (b) and the difference of seabed thickness (sensitivity tests minus benchmark run) compared with benchmark result (c and d). (Note: The range of color bar in the upper panel is different from that in the lower panel). 


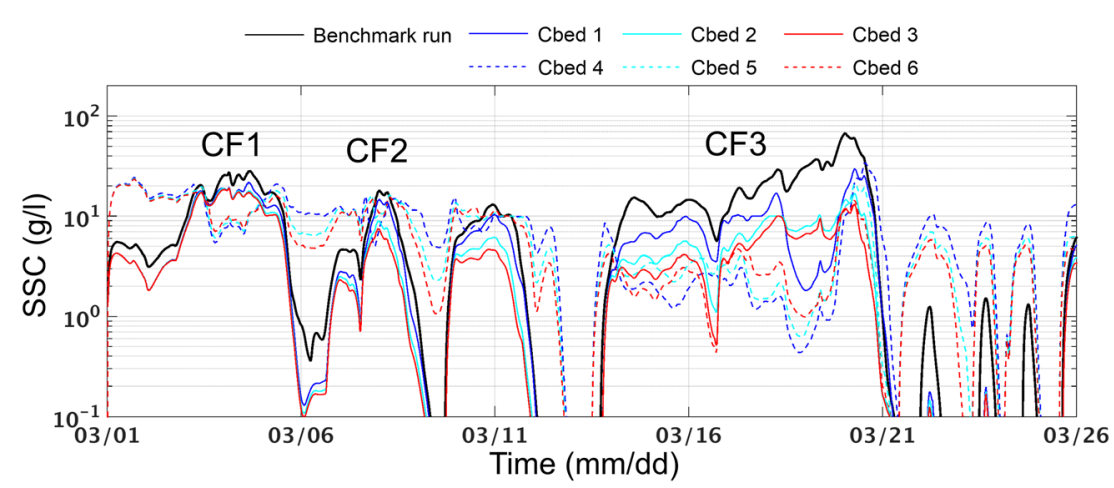

Figure 18. Comparisons of the simulated sediment concentration in the WBL at $\mathrm{T} 1$ station between the benchmark run and cohesive bed tests (Cbed 1-6). The legend is the same as Figure 4.

differences between the sensitivity tests with different $\tau_{\min }$ implies the importance of the surface critical shear stress initialization. The measurements based on sediment cores in receiving basin of the Mississippi River diversions indicated that $\tau_{c r i}$ was around $0.2 \mathrm{~Pa}$ for consolidated sediment, and the value could be smaller for freshly deposited fluvial sediment (Xu, Bentley, et al., 2016). Due to the lack of erodibility measurements over the Atchafalaya shelf, accurate parameterization of cohesive bed behavior is still a challenge in this study. Given the presence of both poorly consolidated fluvial sediment and consolidated relict Holocene sediment off the Chenier Plain (Draut, Kineke, Velasco, et al., 2005), the spatial variation of equilibrium $\tau_{c r i}$ curve should be included in the future to better reproduce WSFM over the Atchafalaya shelf.

\subsection{Model Uncertainties and Future Work}

Our WSFM sediment transport model captured the main features of sediment dispersal induced by both dilute sediment suspension in the water column and fluid muds in the WBL. The unique offshore deposition over the Atchafalaya shelf and along the Chenier Plain was also reproduced. Nevertheless, it is worth noting that there are still processes not considered in our model. Firstly, the model only includes one type of mobilized sediment particle, and interactions between different types of particles (e.g., interparticle collision) were not taken into account. When the volume fraction of particles is larger than $1 \times 10^{-3}$ (i.e., $1 \%$ ), particle-particle collision becomes significant and the collision probability will substantially increase once solid particles exceeds 5\% (Elghobashi, 1994; Wachs, 2009). In aqueous flows, where the fluid is sufficiently viscous, with decreasing sediment size the energy is mostly consumed by fluid viscosity rather than inelastic deformation of the suspended particles. Such process might damp the turbulence and therefore affect the sediment flux (Schmeeckle et al., 2001). Secondly, noncohesive (sand) sediment dynamics was not included in our model because sediment cores with footprint of WSFM depositions off the Chenier Plain were composed primarily of silt and clay (e.g., Denommee et al., 2016, 2018; Rotondo \& Bentley, 2003). However, the field measurements of Flores et al. (2018) documented the occurrence of wave-supported gravity flow on a sandy seabed. This finding has important implications for the WSFM dynamics on the entire Louisiana Shelf: Wave-supported gravity flow might happen on the edge of relict sandy shoals (e.g., Tiger/Trinity and Ship Shoals), where bathymetric slope is steep and sand content is high. To test this hypothesis, bottom boundary layer measurements and WSFM simulation with noncohesive sediment dynamics should be conducted over the sandy shoals in the future. Thirdly, our model so far included the influence of hydrodynamics to sediment dispersal, erosion, and deposition, whereas the feedback of sediment dynamics to hydrodynamics (i.e., viscous fluid mud's wave energy dissipating capacity (Siadatmousavi et al., 2012) and the effect of sediment-induced stable density stratification on turbulence attenuation), which could be significant during energetic events, was not taken into account. For example, it is reported in Sheremet et al. (2005) that both long and short waves over the muddy shelf were lower than that over the sandy shelf during winter storms and hurricanes due to fluid mud-induced wave damping. A fluid mud-induced wave damping algorithm developed by Winterwerp et al. (2007) was included in SWAN and applied to the Guyana coastal system. Prior turbulence-resolving simulations in particle-laden flow also suggest the complexity of turbulence-sediment interactions due to sediment-induced stable density 
stratification, bed erosion, and hindered settling (Cheng, Yu, Hsu, \& Balachandar, 2015; Hsu et al., 2009; Ozdemir et al., 2010, 2011). Therefore, a realistic fluid mud transport simulation in the future should incorporate different types of sediment particles and two-way coupling between sediment dynamics and hydrodynamics to achieve more robust results.

\section{Conclusions}

We incorporated the 2-D WSFM model into the COAWST modeling system and applied it to the Atchafalaya shelf to investigate fluid mud dynamics in March 2008. A WBL model was introduced between the bottommost water column grid cells and top sediment bed grid cells, which accounted for the key sediment exchange processes (e.g., resuspension, vertical settling, diffusion, and horizontal advection) at the water-WBL and WBL-sediment bed boundaries. The simulation results compared well with the field measurements from the Louisiana Shelf, indicating that the model was capable of reproducing both hydroand sediment dynamics during the passage of three cold fronts.

As cold fronts swept across the Atchafalaya shelf, waves were enhanced to $2 \mathrm{~m}$ offshore and $0.7 \mathrm{~m}$ onshore by strong northwesterly winds $(>10 \mathrm{~m} / \mathrm{s})$, and the direction of alongshore current shifted from westward to eastward. Bottom shear stress peaked between the 5- and 10-m isobaths. The river plume expanded seaward during cold fronts due to intensified seaward currents in the bay. Dilute suspended sediment transport in the water column was driven by seaward currents in the Atchafalaya Bay while the intensified eastward alongshore currents transported sediment upcoast. Sediment concentration of WSFM was on the order of 10$100 \mathrm{~g} / \mathrm{L}$, which was more than 10 times higher than that calculated for dilute suspension in the overlying water column. The WSFM transport velocities were directed downslope ranging from $3 \mathrm{~cm} / \mathrm{s}$ in the Atchafalaya Bay to $12 \mathrm{~cm} / \mathrm{s}$ off the Chenier Plain. Over the Atchafalaya shelf, net SSF and WSFM flux in seaward direction were comparable $(0.062$ and $0.084 \mathrm{~kg} / \mathrm{m} / \mathrm{s}$, respectively), and they were much higher than those in alongshore direction. Along the Chenier Plain, the direction of dilute SSF $(0.077 \mathrm{~kg} / \mathrm{m} / \mathrm{s})$ was parallel to the shoreline while WSFM flux $(0.249 \mathrm{~kg} / \mathrm{m} / \mathrm{s})$ was seaward.

The introduction of the WBL WSFM model lowered the simulated SSC and SSF in the water column and allowed the model to represent the lutocline formed between the WBL and the overlying water column in the model. Both simulations (original CSTMS and CSTMS + WBL) reproduced net erosion in the Atchafalaya Bay and net deposition over the Atchafalaya shelf, while the area of erosion nearshore was larger once the WBL WSFM model was included due to the extra seaward WSFM flux. The erosion/deposition pattern along the Chenier Plain changed greatly (onshore erosion $>4 \mathrm{~cm}$ ) because seaward WSFM flux outweighed alongshore SSF.

Acknowledgments

Research support provided through NSF CyberSEES (Award CCF1856359), NASA (Award NNH17ZHA002C), Louisiana Board of Regents (award number NASA/LEQSF(2018-20)-Phase3-11), Bureau of Ocean Energy Management (Cooperative Agreement Award M20AC00007), NSF Coastal SEES (Award EAR-1427389), NSF (Award OCE-20203676), and LSU Foundation Billy and Ann Harrison Endowment for Sedimentary Geology. We are grateful to Dr. Courtney Harris and anonymous reviewers for their comments and suggestions. Specifically, Dr. Harris' three rounds of detailed and constructive comments improved the manuscript a lot. We thank Dr. Alexandru Sheremet of University of Florida and Dr. Peter Traykovski of the Woods Hole Oceanographic Institution for sharing their tripod data. Computational support was provided by the High-Performance Computing Facility (cluster SuperMike II and QueenBee2) at Louisiana State University.
Fluvial sediment discharge variation affected both sediment flux and deposition rate in the Atchafalaya Bay. No substantial difference was simulated with different fluvial sediment discharge, indicating the Atchafalaya shelf is a transport-limited system. Sensitivity tests based on different schemes of settling velocity applied within the WBL indicated that hindered settling effect could enhance seaward transport by keeping sediment in suspension and increasing the density of the fluid mud and thus the downslope WSFM flux. As cohesive bed behavior was applied, sediment concentration in the WBL was sensitive to surface critical shear stress initialization. The importance of seabed consolidation status in WSFM dynamics was enhanced after several rounds of erosion.

\section{Data Availability Statement}

Data used in this study are stored in the LSU mass storage system, and detailed information is posted on the homepage of Coupled Ocean Modeling Group (http://www.oceanography.lsu.edu/xuelab). Model code and data request can be sent to the corresponding author via this webpage.

\section{References}

Adams, C., Witt, E. C., Wang, J., Shaver, D. K., Summers, D., Filali-Meknassi, Y., et al. (2007). Chemical quality of depositional sediments and associated soils in New Orleans and the Louisiana peninsula following Hurricane Katrina. Environmental Science \& Technology, 41(10), 3437-3443. https://doi.org/10.1021/es0620991

Allison, M. A., Demas, C. R., Ebersole, B. A., Kleiss, B. A., Little, C. D., Meselhe, E. A., et al. (2012). A water and sediment budget for the lower Mississippi-Atchafalaya River in flood years 2008-2010: Implications for sediment discharge to the oceans and coastal restoration in Louisiana. Journal of Hydrology, 432-433, 84-97. https://doi.org/10.1016/j.jhydrol.2012.02.020 
Allison, M. A., Kineke, G. C., Gordon, E. S., \& Goñi, M. A. (2000). Development and reworking of a seasonal flood deposit on the inner continental shelf off the Atchafalaya River. Continental Shelf Research, 20(16), 2267-2294. https://doi.org/10.1016/S0278-4343(00) 00070-4

Allison, M. A., \& Neill, C. F. (2002). Accumulation rates and stratigraphic character of the modern Atchafalaya River prodelta, Louisiana. Transactions. Gulf Coast Association of Geological Societies, 52, 1031-1040.

Aplin, A. C., Fleet, A. J., \& Macquaker, J. H. S. (1999). Muds and mudstones: Physical and fluid-flow properties. Geological Society of London, Special Publication, 158(1), 1-8. https://doi.org/10.1144/GSL.SP.1999.158.01.01

Ariathurai, R., \& Arulanandan, K. (1978). Erosion rates of cohesive soils. Journal of the Hydraulics Division, 104, $279-283$.

Bentley, S. J., \& Nittrouer, C. A. (2003). Emplacement, modification, and preservation of event strata on a flood-dominated continental shelf: Eel shelf, Northern California. Continental Shelf Research, 23(16), 1465-1493. https://doi.org/10.1016/j.csr.2003.08.005

Bentley, S. J., Sheremet, A., \& Jaeger, J. M. (2006). Preservation potential of event layers on continental shelves: A model and observations. Continental Shelf Research, 26(17-18), 2108-2124. https://doi.org/10.1016/j.csr.2006.07.003

Bianchi, T. S., Mitra, S., \& McKee, B. A. (2002). Sources of terrestrially-derived organic carbon in lower Mississippi River and Louisiana shelf sediments: Implications for differential sedimentation and transport at the coastal margin. Marine Chemistry, 77(2-3), 211-223. https://doi.org/10.1016/S0304-4203(01)00088-3

Blumberg, A. F., \& Mellor, G. L. (1987). A description of a three-dimensional coastal ocean circulation model. Three-dimensional Coast. Ocean Modelling, 4, 1-16. https://doi.org/10.1029/CO004p0001

Booij, N., Ris, R. C., \& Holthuijsen, L. H. (1999). A third-generation wave model for coastal regions: 1. Model description and validation. Journal of Geophysical Research, 104, 7649-7666.

Butman, B., Aretxabaleta, A. L., Dickhudt, P. J., Dalyander, P. S., Sherwood, C. R., Anderson, D. M., et al. (2014). Investigating the importance of sediment resuspension in Alexandrium fundyense cyst population dynamics in the Gulf of Maine. Deep-Sea Research Part II: Topical Studies in Oceanography, 103, 79-95. https://doi.org/10.1016/j.dsr2.2013.10.011

Caldwell, R. L., \& Edmonds, D. A. (2014). The effects of sediment properties on deltaic processes and morphologies: A numerical modeling study. Journal of Geophysical Research: Earth Surface, 119, 961-982. https://doi.org/10.1002/2013JF002965

Cheng, Z., Yu, X., Hsu, T., \& Balachandar, S. (2015). A numerical investigation of fine sediment resuspension in the wave boundary layerUncertainties in particle inertia and hindered settling. Computational Geosciences, 83, 176-192. https://doi.org/10.1016/j. cageo.2015.07.009

Cheng, Z., Yu, X., Hsu, T.-J., Ozdemir, C. E., \& Balachandar, S. (2015). On the transport modes of fine sediment in the wave boundary layer due to resuspension/deposition: A turbulence-resolving numerical investigation. Journal of Geophysical Research: Oceans, 120, 1918-1936. https://doi.org/10.1002/2014JC010623.Received

Dail, M. B., Reide Corbett, D., \& Walsh, J. P. (2007). Assessing the importance of tropical cyclones on continental margin sedimentation in the Mississippi delta region. Continental Shelf Research, 27(14), 1857-1874. https://doi.org/10.1016/j.csr.2007.03.004

Dankers, P. J. T., \& Winterwerp, J. C. (2007). Hindered settling of mud flocs: Theory and validation. Continental Shelf Research, 27(14), 1893-1907. https://doi.org/10.1016/j.csr.2007.03.005

Denommee, K. C., Bentley, S. J., \& Harazim, D. (2018). Mechanisms of muddy clinothem progradation on the Southwest Louisiana Chenier Plain inner shelf. Geo-Marine Letters, 38(3), 273-285. https://doi.org/10.1007/s00367-017-0525-3

Denommee, K. C., Bentley, S. J., Harazim, D., \& Macquaker, J. H. S. (2016). Hydrodynamic controls on muddy sedimentary-fabric development on the Southwest Louisiana subaqueous delta. Marine Geology, 382, 162-175. https://doi.org/10.1016/j.margeo.2016.09.013

Draut, A. E., Kineke, G. C., Huh, O. K., Grymes, J. M., Westphal, K. A., \& Moeller, C. C. (2005). Coastal mudflat accretion under energetic conditions, Louisiana chenier-plain coast, USA. Marine Geology, 214(1-3), 27-47. https://doi.org/10.1016/j.margeo.2004.10.033

Draut, A. E., Kineke, G. C., Velasco, D. W., Allison, M. A., \& Prime, R. J. (2005). Influence of the Atchafalaya River on recent evolution of the chenier-plain inner continental shelf, northern Gulf of Mexico. Continental Shelf Research, 25(1), 91-112. https://doi.org/10.1016/j. csr.2004.09.002

Egbert, G. D., \& Erofeeva, S. Y. (2002). Efficient inverse modeling of barotropic ocean tides. Journal of Atmospheric and Oceanic Technology, 19(2), 183-204. https://doi.org/10.1175/1520-0426(2002)019<0183:EIMOBO>2.0.CO;2

Elghobashi, S. (1994). On predicting particle-laden turbulent flows. Applied Scientific Research, 52(4), 309-329. https://doi.org/10.1007/ BF00936835

Flather, R. A. (1976). A tidal model of the northwest European continental shelf(Vol. 10, pp. 141-164). Société Royale des Sciences de Liège.

Flores, R. P., Rijnsburger, S., Meirelles, S., Horner-Devine, A. R., Souza, A. J., Pietrzak, J. D., et al. (2018). Wave generation of gravity-driven sediment flows on a predominantly sandy seabed. Geophysical Research Letters, 45, 7634-7645. https://doi.org/10.1029/2018GL077936

Friedrichs, C. T., \& Scully, M. E. (2007). Modeling deposition by wave-supported gravity flows on the Po River prodelta: From seasonal floods to prograding clinoforms. Continental Shelf Research, 27(3-4), 322-337. https://doi.org/10.1016/j.csr.2006.11.002

Friedrichs, C. T., \& Wright, L. D. (2004). Gravity-driven sediment transport on the continental shelf: Implications for equilibrium profiles near river mouths. Coastal Engineering, 51(8-9), 795-811. https://doi.org/10.1016/j.coastaleng.2004.07.010

Fugate, D. C., \& Friedrichs, C. T. (2002). Determining concentration and fall velocity of estuarine particle populations using ADV, OBS and LISST. Continental Shelf Research, 22(11-13), 1867-1886. https://doi.org/10.1016/S0278-4343(02)00043-2

Goñi, M. A., Gordon, E. S., Monacci, N. M., Clinton, R., Gisewhite, R., Allison, M. A., \& Kineke, G. (2006). The effect of Hurricane Lili on the distribution of organic matter along the inner Louisiana shelf (Gulf of Mexico, USA). Continental Shelf Research, 26(17-18), 2260-2280. https://doi.org/10.1016/j.csr.2006.07.017

Gratiot, N., \& Manning, A. J. (2004). An experimental investigation of floc characteristics in a diffusive turbulent flow. Journal of Coastal Research, 105-113.

Haidvogel, D. B., Arango, H., Budgell, W. P., Cornuelle, B. D., Curchitser, E., Di Lorenzo, E., et al. (2008). Ocean forecasting in terrain-following coordinates: Formulation and skill assessment of the Regional Ocean Modeling System. Journal of Computational Physics, 227(7), 3595-3624. https://doi.org/10.1016/j.jcp.2007.06.016

Hale, R. P., \& Ogston, A. S. (2015). In situ observations of wave-supported fluid-mud generation and deposition on an active continental margin. Journal of Geophysical Research: Earth Surface, 120, 2357-2373. https://doi.org/10.1002/2015JF003630

Hale, R. P., Ogston, A. S., Walsh, J. P., \& Orpin, A. R. (2014). Sediment transport and event deposition on the Waipaoa River Shelf, New Zealand. Continental Shelf Research, 86, 52-65. https://doi.org/10.1016/j.csr.2014.01.009

Hanebuth, T. J. J., Lantzsch, H., \& Nizou, J. (2015). Mud depocenters on continental shelves-Appearance, initiation times, and growth dynamics. Geo-Marine Letters, 35(6), 487-503. https://doi.org/10.1007/s00367-015-0422-6

Harris, C. K., Traykovski, P., \& Geyer, W. R. (2004). Including a near-bed turbid layer in a three dimensional sediment transport model with application to the Eel River shelf, northern California. In Estuarine and coastal modeling (2003) (pp. 784-803). 
Harris, C. K., Traykovski, P. A., \& Geyer, W. R. (2005). Flood dispersal and deposition by near-bed gravitational sediment flows and oceanographic transport: A numerical modeling study of the Eel River shelf, northern California. Journal of Geophysical Research, 110, C09025. https://doi.org/10.1029/2004JC002727

Harris, C. K., \& Wiberg, P. (2002). Across-shelf sediment transport: Interactions between suspended sediment and bed sediment. Journal of Geophysical Research, 107(C1), 3008. https://doi.org/10.1029/2000JC000634

Hill, P. S., Milligan, T. G., \& Geyer, W. R. (2000). Controls on effective settling velocity of suspended sediment in the Eel River flood plume. Continental Shelf Research, 20(16), 2095-2111. https://doi.org/10.1016/S0278-4343(00)00064-9

Hsu, T. J., Ozdemir, C. E., \& Traykovski, P. A. (2009). High-resolution numerical modeling of wave-supported gravity-driven mudflows. Journal of Geophysical Research, 114, C05014. https://doi.org/10.1029/2008JC005006

Huang, P., Li, T., Li, A., Yu, X., \& Hu, N.-J. (2014). Distribution, enrichment and sources of heavy metals in surface sediments of the North Yellow Sea. Continental Shelf Research, 73, 1-13. https://doi.org/10.1016/j.csr.2013.11.014

Hwang, K.-N. (1989). Erodibility of fine sediment in wave-dominated environments (MS thesis) (pp. 1-166). University of Florida.

Jacob, R., Larson, J., \& Everest, O. (2005). M x N communication and parallel interpolation in community climate system model version 3 using the model coupling toolkit. International Journal of High Performance Computing Applications, 19(3), 293-307. https://doi.org/ $10.1177 / 1094342005056116$

Jaramillo, S. (2008). Observations of wave-sediment interactions on a muddy shelf(PhD dissertation). Gainesville, FL: University of Florida.

Jaramillo, S., Sheremet, A., Allison, M. A., Reed, A. H., \& Holland, K. T. (2009). Wave-mud interactions over the muddy Atchafalaya subaqueous clineform, Louisiana, United States: Wave-supported sediment transport. Journal of Geophysical Research, 114, C04002. https://doi.org/10.1029/2008JC0048212009

Kineke, G. C., Higgins, E. E., Hart, K., \& Velasco, D. (2006). Fine-sediment transport associated with cold-front passages on the shallow shelf, Gulf of Mexico. Continental Shelf Research, 26(17-18), 2073-2091. https://doi.org/10.1016/j.csr.2006.07.023

Kolker, A. S., Li, C., Walker, N. D., Pilley, C., Ameen, A. D., Boxer, G., et al. (2014). The impacts of the great Mississippi/Atchafalaya River flood on the oceanography of the Atchafalaya shelf. Continental Shelf Research, 86, 17-33. https://doi.org/10.1016/j.csr.2014.04.023

Kuehl, S. A., DeMaster, D. J., \& Nittrouer, C. A. (1986). Nature of sediment accumulation on the Amazon continental shelf. Continental Shelf Research, 6(1-2), 209-225. https://doi.org/10.1016/0278-4343(86)90061-0

Liu, J., Liang, J., Xu, K., Chen, Q., \& Ozdemir, C. E. (2019). Modeling sediment flocculation in Langmuir turbulence. Journal of Geophysical Research: Oceans, 124, 7883-7907. https://doi.org/10.1029/2019JC015197

Ma, Y., Friedrichs, C. T., Harris, C. K., \& Wright, L. D. (2010). Deposition by seasonal wave- and current-supported sediment gravity flows interacting with spatially varying bathymetry: Waiapu shelf, New Zealand. Marine Geology, 275(1-4), 199-211. https://doi.org/10.1016/j. margeo.2010.06.001

Ma, Y., Wright, L. D., \& Friedrichs, C. T. (2008). Observations of sediment transport on the continental shelf off the mouth of the Waiapu River, New Zealand: Evidence for current-supported gravity flows. Continental Shelf Research, 28(4-5), 516-532. https://doi.org/ 10.1016/j.csr.2007.11.001

Macquaker, J. H. S., Bentley, S. J., \& Bohacs, K. M. (2010). Wave-enhanced sediment-gravity flows and mud dispersal across continental shelves: Reappraising sediment transport processes operating in ancient mudstone successions. Geology, 38(10), 947-950. https://doi. org/10.1130/G31093.1

Madsen, O. S. (1994). Spectral wave-current bottom boundary layer flows. Coastal Engineering Proceedings, 1, 384-398. https://doi.org/ 10.9753/icce.v24

Maerz, J., Verney, R., Wirtz, K., \& Feudel, U. (2011). Modeling flocculation processes: Intercomparison of a size class-based model and a distribution-based model. Continental Shelf Research, 31(10), S84-S93. https://doi.org/10.1016/j.csr.2010.05.011

Martin, J. F. (2002). Emergy valuation of diversions of river water to marshes in the Mississippi River Delta. Ecological Engineering, 18(3), 265-286. https://doi.org/10.1016/S0925-8574(01)00082-9

McAnally, W. H., Teeter, A., Schoellhamer, D., Friedrichs, C., Hamilton, D., Hayter, E., et al. (2007). Management of fluid mud in estuaries, bays, and lakes. II: Measurement, modeling, and management. Journal of Hydraulic Engineering, 133(1), 9-22. https://doi.org/10.1061/ (ASCE)0733-9429(2007)133:1(9)

McSweeney, J. M., Chant, R. J., Wilkin, J. L., \& Sommerfield, C. K. (2017). Suspended-sediment impacts on light-limited productivity in the Delaware estuary. Estuaries and Coasts, 40(4), 977-993. https://doi.org/10.1007/s12237-016-0200-3

Meade, R. H., \& Moody, J. A. (2010). Causes for the decline of suspended-sediment discharge in the Mississippi River system, 1940-2006. Hydrological Processes: An International Journal, 24, 35-49. https://doi.org/10.1002/hyp

Mehta, A. J. (1996). Interaction between fluid mud and water waves. In Environmental hydraulics (pp. 153-187). New York: Springer.

Mehta, A. J., Samsami, F., Khare, Y. P., \& Sahin, C. (2014). Fluid mud properties in nautical depth estimation. Journal of Waterway, Port, Coastal, and Ocean Engineering, 140(2), 210-222. https://doi.org/10.1061/(ASCE)WW.1943-5460.0000228

Miles, T., Seroka, G., Kohut, J., Schofield, O., \& Glenn, S. (2015). Glider observations and modeling of sediment transport in Hurricane Sandy. Journal of Geophysical Research: Oceans, 120, 1771-1791. https://doi.org/10.1002/2014JC010474

Miller, A. J., \& Kuehl, S. A. (2010). Shelf sedimentation on a tectonically active margin: A modern sediment budget for poverty continental shelf, New Zealand. Marine Geology, 270(1-4), 175-187. https://doi.org/10.1016/j.margeo.2009.10.018

Milligan, T. G., \& Hill, P. S. (1998). A laboratory assessment of the relative importance of turbulence, particle composition, and concentration in limiting maximal floc size and settling behaviour. Journal of Sea Research, 39(3-4), 227-241. https://doi.org/10.1016/S13851101(97)00062-2

Moriarty, J., Harris, C., \& Hadfield, M. (2014). A hydrodynamic and sediment transport model for the Waipaoa Shelf, New Zealand: Sensitivity of fluxes to spatially-varying erodibility and model nesting. Journal of Marine Science and Engineering, 2(2), 336-369. https:// doi.org/10.3390/jmse2020336

Moriarty, J. M., Harris, C. K., \& Hadfield, M. G. (2015). Event-to-seasonal sediment dispersal on the Waipaoa River shelf, New Zealand: A numerical modeling study. Continental Shelf Research, 110, 108-123. https://doi.org/10.1016/j.csr.2015.10.005

Munk, W. H., \& Anderson, E. R. (1948). Note on the theory of the thermocline. Journal of Marine Research, 7, $276-295$.

Neill, C. F., \& Allison, M. A. (2005). Subaqueous deltaic formation on the Atchafalaya shelf, Louisiana. Marine Geology, 214(4), 411-430. https://doi.org/10.1016/j.margeo.2004.11.002

Nittrouer, C. A., DeMaster, D. J., Figueiredo, A. G., \& Rine, J. M. (1991). AmasSeds: An interdisciplinary investigation of a complex coastal environment. Oceanography, 4(1), 3-7. https://doi.org/10.5670/oceanog.1991.14

Ogston, A. S., Cacchione, D. A., Sternberg, R. W., \& Kineke, G. C. (2000). Observations of storm and river flood-driven sediment transport on the northern California continental shelf. Continental Shelf Research, 20(16), 2141-2162. https://doi.org/10.1016/S02784343(00)00065-0 
Olabarrieta, M., Geyer, W. R., Coco, G., Friedrichs, C. T., \& Cao, Z. (2018). Effects of density-driven flows on the long-term morphodynamic evolution of funnel-shaped estuaries. Journal of Geophysical Research: Earth Surface, 123, 2901-2924. https://doi.org/10.1029/ 2017JF004527

Orlanski, I. (1976). A simple boundary condition for unbounded hyperbolic flows. Journal of Computational Physics, 21(3), 251-269. https://doi.org/10.1016/0021-9991(76)90023-1

Ozdemir, C. E., Hsu, T. J., \& Balachandar, S. (2010). A numerical investigation of fine particle laden flow in an oscillatory channel: The role of particle-induced density stratification. Journal of Fluid Mechanics, 665, 1-45. https://doi.org/10.1017/S0022112010003769

Ozdemir, C. E., Hsu, T. J., \& Balachandar, S. (2011). A numerical investigation of lutocline dynamics and saturation of fine sediment in the oscillatory boundary layer. Journal of Geophysical Research, 116, C09012. https://doi.org/10.1029/2011JC007185

Radakovitch, O., Charmasson, S., Arnaud, M., \& Bouisset, P. (1999). ${ }^{210} \mathrm{~Pb}$ and caesium accumulation in the Rhone delta sediments. Estuarine, Coastal and Shelf Science, 48(1), 77-92. https://doi.org/10.1006/ecss.1998.0405

Rinehimer, J. P., Harris, C. K., Sherwood, C. R., \& Sanford, L. P. (2008). Estimating cohesive sediment erosion and consolidation in a muddy, tidally-dominated environment: Model behavior and sensitivity. In Estuarine and coastal modeling (2007) (pp. 819-838).

Ross, M. A., \& Mehta, A. J. (1989). On the mechanics of lutoclines and fluid mud. Journal of Coastal Research, 51-62.

Rotondo, K. A., \& Bentley, S. J. (2003). Deposition and resuspension offluid muds on the western Louisiana inner continental shelf: Gulf Coast Association of Geological Societies Transactions 53.

Safak, I., Sheremet, A., Allison, M. A., \& Hsu, T. J. (2010). Bottom turbulence on the muddy Atchafalaya shelf, Louisiana, USA. Journal of Geophysical Research, 115, C12019. https://doi.org/10.1029/2010JC006157

Sahin, C., Safak, I., Sheremet, A., \& Mehta, A. J. (2012). Observations on cohesive bed reworking by waves: Atchafalaya shelf, Louisiana. Journal of Geophysical Research, 117, C09025. https://doi.org/10.1029/2011JC007821

Sanford, L. P., \& Maa, J. P.-Y. (2001). A unified erosion formulation for fine sediments. Marine Geology, 179(1-2), 9-23. https://doi.org/ 10.1016/S0025-3227(01)00201-8

Sanford, L. P., Suttles, S. E., \& Halka, J. P. (2001). Reconsidering the physics of the Chesapeake Bay estuarine turbidity maximum. Estuaries, 24(5), 655-669. https://doi.org/10.2307/1352874

Schmeeckle, M. W., Nelson, J. M., Pitlick, J., \& Bennett, J. P. (2001). Interparticle collision of natural sediment grains in water. Water Resources Research, 37(9), 2377-2391. https://doi.org/10.1029/2001WR000531

Scully, M. E., Friedrichs, C. T., \& Wright, L. D. (2003). Numerical modeling of gravity-driven sediment transport and deposition on an energetic continental shelf: Eel River, northern California. Journal of Geophysical Research, 108(C4), 3120. https://doi.org/10.1029/ 2002JC001467

Shchepetkin, A. F., \& McWilliams, J. C. (2005). The regional oceanic modeling system (ROMS): A split-explicit, free-surface, topographyfollowing-coordinate oceanic model. Ocean Modelling, 9(4), 347-404. https://doi.org/10.1016/j.ocemod.2004.08.002

Shen, X., \& Maa, J. P.-Y. (2016). Numerical simulations of particle size distributions: Comparison with analytical solutions and kaolinite flocculation experiments. Marine Geology, 379, 84-99. https://doi.org/10.1016/j.margeo.2016.05.014

Sheremet, A., Jaramillo, S., Su, S. F., Allison, M. A., \& Holland, K. T. (2011). Wave-mud interaction over the muddy Atchafalaya subaqueous clinoform, Louisiana, United States: Wave processes. Journal of Geophysical Research, 116, C06005. https://doi.org/10.1029/ 2010JC006644

Sheremet, A., Mehta, A. J., Liu, B., \& Stone, G. W. (2005). Wave-sediment interaction on a muddy inner shelf during Hurricane Claudette. Estuarine, Coastal and Shelf Science, 63(1-2), 225-233. https://doi.org/10.1016/j.ecss.2004.11.017

Sheremet, A., \& Stone, G. W. (2003). Observations of nearshore wave dissipation over muddy sea beds. Journal of Geophysical Research, 108(C11), 3357. https://doi.org/10.1029/2003JC001885

Sherwood, C. R., Aretxabaleta, A. L., Harris, C. K., Paul Rinehimer, J., Verney, R., \& Ferré, B. (2018). Cohesive and mixed sediment in the Regional Ocean Modeling System (ROMS v3.6) implemented in the Coupled Ocean-Atmosphere-Wave-Sediment Transport Modeling System (COAWST r1234). Geoscientific Model Development, 11(5), 1849-1871. https://doi.org/10.5194/gmd-11-1849-2018

Siadatmousavi, S. M., Allahdadi, M. N., Chen, Q., Jose, F., \& Roberts, H. H. (2012). Simulation of wave damping during a cold front over the muddy Atchafalaya shelf. Continental Shelf Research, 47, 165-177. https://doi.org/10.1016/j.csr.2012.07.012

Skamarock, W. C., Klemp, J. B., Dudhi, J., Gill, D. O., Barker, D. M., Duda, M. G., et al. (2005). A description of the advanced research WRF version 3. Technical Report 113. https://doi.org/10.5065/D6DZ069T

Smith, J. D., \& McLean, S. R. (1977). Spatially averaged flow over a wavy surface. Journal of Geophysical Research, 82(12), $1735-1746$. https://doi.org/10.1029/JC082i012p01735

Tarpley, D. R. N., Harris, C. K., Friedrichs, C. T., \& Sherwood, C. R. (2019). Tidal variation in cohesive sediment distribution and sensitivity to flocculation and bed consolidation in an idealized, partially mixed estuary. Journal of Marine Science and Engineering, 7(10), 334. https://doi.org/10.3390/jmse7100334

Törnqvist, T. E., Kidder, T. R., Autin, W. J., van der Borg, K., de Jong, A. F. M., Klerks, C. J. W., et al. (1996). A revised chronology for Mississippi River subdeltas. Science, 273, 1693-1696.

Traykovski, P., Geyer, W. R., Irish, J. D., \& Lynch, J. F. (2000). The role of wave-induced density-driven fluid mud flows for cross-shelf transport on the Eel River continental shelf. Continental Shelf Research, 20(16), 2113-2140. https://doi.org/10.1016/S02784343(00)00071-6

Traykovski, P., Trowbridge, J., \& Kineke, G. C. (2015). Mechanisms of surface wave energy dissipation over a high-concentration sediment suspension. Journal of Geophysical Research: Oceans, 120, 1638-1681. https://doi.org/10.1002/2014JC010245.Received

Traykovski, P., Wiberg, P. L., \& Geyer, W. R. (2007). Observations and modeling of wave-supported sediment gravity flows on the Po prodelta and comparison to prior observations from the Eel shelf. Continental Shelf Research, 27(3-4), 375-399. https://doi.org/10.1016/j. csr.2005.07.008

Trefry, J. H., \& Presley, B. J. (1976). Heavy metals in sediments from San Antonio Bay and the northwest Gulf of Mexico. Environmental Geology, 1(5), 283-294. https://doi.org/10.1007/BF02676717

Trowbridge, J. H., \& Kineke, G. C. (1994). Structure and dynamics of fluid muds on the Amazon continental shelf. Journal of Geophysical Research, 99(C1), 865-874. https://doi.org/10.1029/93JC02860

Van Leussen, W., \& Cornelisse, J. M. (1993). The determination of the sizes and settling velocities of estuarine flocs by an underwater video system. Netherlands. Journal of Sea Research, 31(3), 231-241. https://doi.org/10.1016/0077-7579(93)90024-M

Wachs, A. (2009). A DEM-DLM/FD method for direct numerical simulation of particulate flows: Sedimentation of polygonal isometric particles in a Newtonian fluid with collisions. Computers and Fluids, 38(8), 1608-1628. https://doi.org/10.1016/j.compfluid.2009.01.005

Walker, N. D., \& Hammack, A. B. (2000). Impacts of winter storms on circulation and sediment transport: Atchafalaya-Vermilion Bay region, Louisiana, USA. Journal of Coastal Research, 16, 996-1010. https://doi.org/10.2307/4300118 
Walsh, J. P., \& Nittrouer, C. A. (2009). Understanding fine-grained river-sediment dispersal on continental margins. Marine Geology, 263(1-4), 34-45. https://doi.org/10.1016/j.margeo.2009.03.016

Wang, H., Bi, N., Wang, Y., Saito, Y., \& Yang, Z. (2010). Tide-modulated hyperpycnal flows off the Huanghe (Yellow River) mouth, China. Earth Surface Processes and Landforms, 35(11), 1315-1329. https://doi.org/10.1002/esp.2032

Wang, H., Yang, Z., Li, G., \& Jiang, W. (2006). Wave climate modeling on the abandoned Huanghe (Yellow River) delta lobe and related deltaic Erosion. Journal of Coastal Research, 224, 906-918. https://doi.org/10.2112/03-0081.1

Warner, J. C., Armstrong, B., He, R., \& Zambon, J. B. (2010). Development of a coupled ocean-atmosphere-wave-sediment transport (COAWST) modeling system. Ocean Modelling, 35(3), 230-244. https://doi.org/10.1016/j.ocemod.2010.07.010

Warner, J. C., Sherwood, C. R., Signell, R. P., Harris, C. K., \& Arango, H. G. (2008). Development of a three-dimensional, regional, coupled wave, current, and sediment-transport model. Computational Geosciences, 34(10), 1284-1306. https://doi.org/10.1016/j cageo.2008.02.012

Wells, J. T., Chinburg, S. J., \& Coleman, J. M. (1984). The Atchafalaya River Delta, Report 4: Generic analysis of Delta Development (pp. 82-15). Vicksburg, MS: US Army Corps of Engineers.

Wells, J. T., \& Kemp, G. P. (1981). Atchafalaya mud stream and recent mudflat progradation: Louisiana chenier plain, Gulf Coast Association of Geological Societies Transaction 31 (pp. 409-416). Gulf Coast Association of Geological Societies.

Williams, S. J., Arsenault, M. A., Buczkowski, B. J., Reid, J. A., Flocks, J., Kulp, M. A., et al. (2007). Surficial sediment character of the Louisiana offshore continental shelf region: A GIS compilation. U.S. Geological Survey.

Winterwerp, J. C. (2002). On the flocculation and settling velocity of estuarine mud. Continental Shelf Research, 22(9), 1339-1360. https:// doi.org/10.1016/S0278-4343(02)00010-9

Winterwerp, J. C., Graaff, R. F. D., Groeneweg, J., \& Luijendijk, A. P. (2007). Modelling of wave damping at Guyana mud coast. Coastal Engineering, 54(3), 249-261. https://doi.org/10.1016/j.coastaleng.2006.08.012

Wolanski E., Asaeda T., \& Imberger J. (1989). Mixing across a lutocline. Limnology and Oceanography, 34(5), 931-938. https://doi.org/ 10.4319/lo.1989.34.5.0931

Wright, L. D., \& Friedrichs, C. T. (2006). Gravity-driven sediment transport on continental shelves: A status report. Continental Shelf Research, 26(17-18), 2092-2107. https://doi.org/10.1016/j.csr.2006.07.008

Wright, L. D., Friedrichs, C. T., Kim, S. C., \& Scully, M. E. (2001). Effects of ambient currents and waves on gravity-driven sediment transport on continental shelves. Marine Geology, 175(1-4), 25-45. https://doi.org/10.1016/S0025-3227(01)00140-2

Xu, F., Wang, D.-P., \& Riemer, N. (2010). An idealized model study of flocculation on sediment trapping in an estuarine turbidity maximum. Continental Shelf Research, 30(12), 1314-1323. https://doi.org/10.1016/j.csr.2010.04.014

Xu, K., Bentley, S. J., Robichaux, P., Sha, X., \& Yang, H. (2016). Implications of texture and erodibility for sediment retention in receiving basins of coastal Louisiana diversions. Water (Switzerland), 8(1), 1, 26-19. https://doi.org/10.3390/w8010026

Xu, K., Harris, C. K., Hetland, R. D., \& Kaihatu, J. M. (2011). Dispersal of Mississippi and Atchafalaya sediment on the Texas-Louisiana shelf: Model estimates for the year 1993. Continental Shelf Research, 31(15), 1558-1575. https://doi.org/10.1016/j.csr.2011.05.008

Xu, K., Mickey, R. C., Chen, Q., Harris, C. K., Hetland, R. D., Hu, K., \& Wang, J. (2016). Shelf sediment transport during hurricanes Katrina and Rita. Computational Geosciences, 90, 24-39. https://doi.org/10.1016/j.cageo.2015.10.009

Xue, Z., He, R., Liu, J. P., \& Warner, J. C. (2012). Modeling transport and deposition of the Mekong River sediment. Continental Shelf Research, 37, 66-78. https://doi.org/10.1016/j.csr.2012.02.010

Zang, Z., Xue, Z. G., Bao, S., Chen, Q., Walker, N. D., Haag, A. S., et al. (2018). Numerical study of sediment dynamics during hurricane Gustav. Ocean Modelling, 126, 29-42. https://doi.org/10.1016/j.ocemod.2018.04.002

Zang, Z., Xue, Z. G., Xu, K., Bentley, S. J., Chen, Q., D'Sa, E. J., \& Ge, Q. (2019). A two decadal (1993-2012) numerical assessment of sediment dynamics in the northern Gulf of Mexico. Water, 11(5), 938. https://doi.org/10.3390/w11050938

Zeng, X., He, R., Xue, Z., Wang, H., Wang, Y., Yao, Z., et al. (2015). River-derived sediment suspension and transport in the Bohai, Yellow, and East China seas: A preliminary modeling study. Continental Shelf Research, 111, 112-125. https://doi.org/10.1016/j.csr.2015.08.015 